enorden 



\section{Nordic Public Sector Cloud Computing - a discussion paper}


Nordic Public Sector Cloud Computingb - a discussion paper

TemaNord 2011:566

ISBN 978-92-893-2286-7

(c) Nordic Council of Ministers, Copenhagen 2012

Print: Kailow Express ApS

Copies: 200

Printed in Denmark

This publication has been published with financial support by the Nordic Council of Ministers. But the contents of this publication do not necessarily reflect the views, policies or recommendations of the Nordic Council of Ministers.

\section{Nordic co-operation}

Nordic co-operation is one of the world's most extensive forms of regional collaboration, involving Denmark, Finland, Iceland, Norway, Sweden, and Faroe Islands, Greenland, and Åland.

Nordic co-operation has firm traditions in politics, the economy, and culture. It plays an important role in European and international collaboration, and aims at creating a strong Nordic community in a strong Europe.

Nordic co-operation seeks to safeguard Nordic and regional interests and principles in the global community. Common Nordic values help the region solidify its position as one of the world's most innovative and competitive.

\section{Nordic Council of Ministers}

Ved Stranden 18

DK-1061 København K

Phone (+45) 33960200

\section{www.norden.org}




\section{Content}

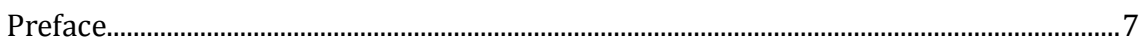

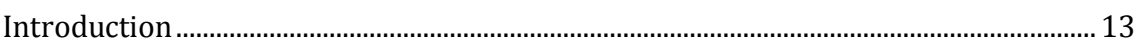

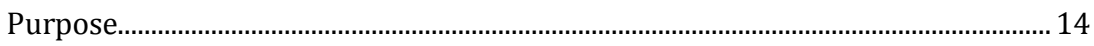

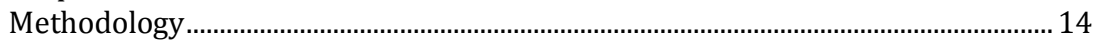

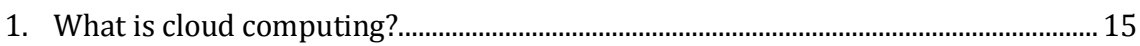

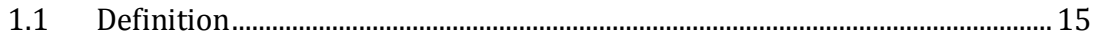

1.2 Benefits of cloud computing ............................................................................... 17

1.3 Cloud computing has the potential to act as a catalyst for public

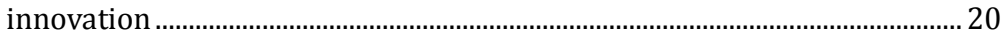

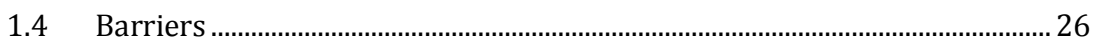

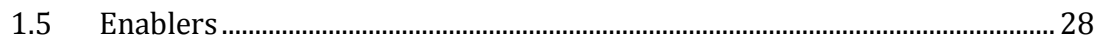

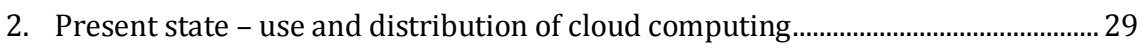

2.1 The Nordic countries...................................................................................... 29

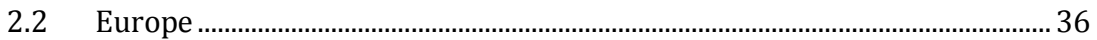

2.3 The United States................................................................................................... 37

3. Why Nordic cooperation on public sector cloud computing?................................... 41

3.1 Cooperation can lead to faster realisation of potential................................... 41

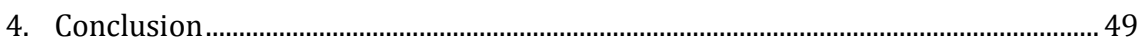

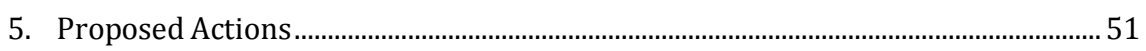

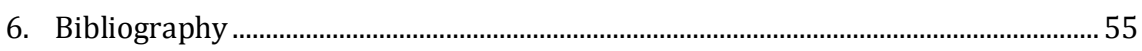

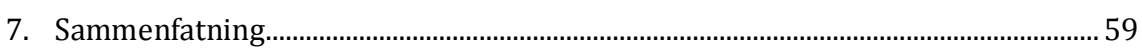

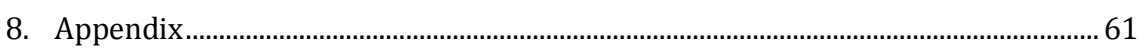

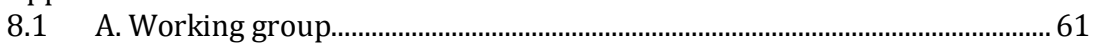

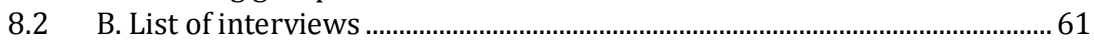





\section{Preface}

Facing a future with scarce resources and increasing pressure on budgets, the public sector in the Nordic countries has an urgent need to streamline and develop its use of IT.

Cloud computing offers an opportunity to do just that. Using cloud computing, public authorities in the Nordic countries can save money on operation and maintenance of IT. At the same time cloud computing gives the public sector a possibility to increase flexibility and a greater opportunity to enable innovation and growth. Finally, the use of cloud computing can reduce power consumption in server rooms, which will have a good effect on our climate.

Cloud computing is here to stay. Several large nations like the United States, India and China have had an active cloud computing agenda for several years. If we in the Nordic countries want to make our influence felt and achieve a quick profit realisation, we must start working together on cloud computing now.

Therefore, the Informal Forum of IT Directors in the Nordic Council of Ministers has initiated this report in the attempt to launch a discussion on wether there should be a Nordic cooperation on cloud computing and what it could focus on. We see the report as the first step of this discussion, and we look forward to hear the different Nordic stakeholders articulate their views on this matter. The report offers the Nordic countries a view of how to understand cloud computing - and more importantly, what potential lie in Nordic cooperation on cloud computing. The report proposes Nordic cooperation on specific areas. We would like to hear from other stakeholders, whether or not these areas are considered the right areas for Nordic cooperation.

The Nordic countries have a solid foundation for taking up cloud computing due to the high level of e-readiness, both when it comes to infrastructure and adaption of new technology. The Nordic countries share a very strong foundation, which we can use to move forward and become a forerunner when it comes to cloud computing.

Besides this many of the barriers associated with the use of cloud computing in the public sector are similar across the Nordic region. Thus we believe, that these barriers might be overcome faster with close cooperation among the Nordic countries. It is our vision that the Nordic countries could establish themselves as a driving force for cloud computing in the public sector. We hope this report will inspire and lead to increased Nordic cooperation.

The Informal Forum of IT Directors 
- Lars Frelle-Petersen, Deputy Director, Agency for Digitisation, Denmark.

- Timo Valli, ICT-director, Ministry of Finance, Finland.

- Guðbjörg Sigurðardóttir, Director, Ministry of Interior, Iceland. Katarina de Brisis, Deputy Director General, Department of ICT policy and public sector reform, Ministry of Government Administration and Reform, Norway.

- Magnus Enzell, Senior Adviser, Ministry of Enterprise, Division for ITpolicy, Sweden. 


\section{Executive summary}

\section{Challenges of the public sector}

The public sector is facing a future with scarce resources and increasing pressure on budgets. Economic and demographic challenges place a demand on the public sector to be more efficient and innovative. Put plainly, the public sector will have to deliver more with less, without compromising the quality of services in the years to come. New demands are emerging from a population with increasing access to broadband and mobile devices, as well as traditional demands are diminishing. Some public services no longer live up to the requirements. The demands on the public sector are reflected in the national IT strategies of the respective countries, which - among other things - focus on user centric, cost efficient IT in the public sector.

\section{Possible benefits of cloud computing}

It is widely recognised that cloud computing has the potential to bring advantages to public and private sector companies alike. This study outlines several benefits of cloud computing:

- Cost effectiveness means that public sector companies can avoid costly asset acquisitions and reduce maintenance

- On-demand self-service can save the procurer from unnescessary interaction with a lot of service providers

- Scalability adds to the flexibility of the solutions and makes a solution more cost effective because it is pay-per-use

- Quality of service means that resource usage can be monitored, controlled and reported

- Implementation speed and time-to-market is accelerated

- Innovation is a profound need of the public sector. Innovation processes are supported by the faster time-to-marked, the architecture of cloud computing which facilitates services across systems and organizational borders, and the collaboration services in the cloud

- Device- and location independency makes it possible to access the cloud solution from anywhere, which is well in sync with public strategies of serving the citizen when and where it is needed 
- Green savings are nessecary in a world where public institutions as well as private enterprises must consider their $\mathrm{CO} 2$ emission. Green savings are realized by a reduction of hardware and unnecessary power consumtion as well as more effective cooling

- Reliability and business continuity because the system is designed to instantly fall back to a secondary data center if the primary data center becomes unavailable

- Efficiency because of the reduced need for internal support and service functions

- Security tools are cheaper when implemented at a larger scale, thus giving the responsible data processor an option to implement higher quality security tools and extensive auditing mechanisms at a marginal extra cost

\section{Barriers to realizing the benefits}

However, there are still barriers towards fully embracing cloud technology and reaping the benefits of this technology. The barriers most commonly mentioned are the legal issues regarding data protection. The Nordic authorities (as well as private enterprises) will have to make sure that personal data (sensitive as well as non-sensitive) will not be handled in countries outside the EU/EES that do not comply with the Safe Harbor agreement (US companies) or similar. Otherwise, it will be necessary to make special agreements with the national regulatory authorities.

Furthermore, the loss of governance is a barrier toward embracing cloud because the procurer cedes control to the provider on a number of issues, such as security.

Cloud technologies are not designed with interoperability in mind, which makes it difficult to scale across cloud providers. Overall, this stifles competition and locks consumers to a single provider (vendor lock-in).

Finally, today existing business applications are not delivered in the cloud to a large extend and it has proved difficult to integrate cloud solutions with existing applications.

These barriers seem to have a greater effect on the public sectors of the Nordic countries than in the United States, where the "Cloud First" policy expresses a will to move public services to the cloud.

\section{Present state in the Nordic region}

The Nordic public sectors are in a good position to increase the use of cloud computing and realise the potential benefits regarding cost effectiveness and increased flexibility. At the macro level, the Nordic countries have similar visions for the welfare state and a set of common chal- 
lenges. There is a demand in the whole region for more effective use of IT in the public sector as well as delivery of fast and effective services to enterprises, other public institutions and citizens. Furthermore, Nordic innovation capabilities are world leading and the Nordic countries are ranked highly in different e-readiness indexes.

The research for the study at hand shows that companies and public administrations in the Nordic countries have shown interest in cloud computing and are using it to some extent. However, this is true to a much lesser extent in Iceland than in the other Nordic countries.

\section{Present state - a broader perspective}

In both the EU and US, cloud computing is on the agenda. The European Commission is working on a cloud computing strategy that will be presented in 2012. The commission is convinced that companies can drastically reduce information technology costs, help governments supply services at a lower cost and save energy by making more efficient use of hardware.

In the United States, the Federal Cloud Computing Strategy and the so called "Cloud First" policy requires the different agencies to name three systems to be moved to the cloud within 18 months.

\section{Nordic cooperation on cloud computing}

In this study, it is argued that there are several benefits of Nordic cooperation on public sector cloud computing. Cloud computing has the potential to function as a driver for public innovation. Nordic cooperation will lead to faster realisation of the benefits of cloud computing at the national level.

There is a need for public innovation. This study argues that cloud computing as an emerging technology in itself is a disruption that can fuel the innovation process. The technology encourages change in the way public organisations operate and interact with citizens.

Nordic cooperation on cloud computing will lead to faster realisation of the benefits of cloud computing. The most successful public benefit realisation initiatives within IT today is consolidating administrative areas, user-driven solution, cross-sector focus and spillover and privatepublic cooperation. Nordic cooperation focusing on the right issues together with successful implementation of common cloud initiatives can give these successful areas even more potential. Benefit realisation can happen faster with Nordic cooperation, than cooperation between other countries, because of the similarities between the Nordic public sectors as well as the Nordic countries' visions for the welfare state. Further- 
more, Nordic cooperation can bring a level of economy of scale into the solutions, which cannot be achieved on the national level.

\section{Proposed actions}

To ensure that cooperation on cloud computing in the Nordic region is a high priority, a formalised working group or cooperation body should be established. The working group will work on a range of initiatives, divided into five areas:

- Knowledge sharing

- Regulations

- Standardisation

- Procurement processes and tools

- Attracting datacenters

\begin{tabular}{|c|c|c|c|c|}
\hline Working Group & Nordic Pl & blic Cloud Co & peration & \\
\hline $\begin{array}{c}\text { Knowledge } \\
\text { Sharing }\end{array}$ & Regulations & Standardisation & $\begin{array}{l}\text { Procurement } \\
\text { processes }\end{array}$ & $\begin{array}{l}\text { Attracting } \\
\text { Datacenters }\end{array}$ \\
\hline $\begin{array}{l}\text { Products of } \\
\text { cooperation }\end{array}$ & & & & \\
\hline $\begin{array}{l}\text { - Reference cases } \\
\text { - Vendor solutions } \\
\text { overview } \\
\text { - Monitoring } \\
\text { overview } \\
\text { - Establishment of } \\
\text { Annual Public } \\
\text { Cloud Innovation } \\
\text { Award }\end{array}$ & $\begin{array}{l}\text { - Overview of } \\
\text { decision made by } \\
\text { law } \\
\text { - Cooperation with } \\
\text { Nordic data } \\
\text { protection } \\
\text { agencies }\end{array}$ & $\begin{array}{l}\text { - Guidelines and } \\
\text { standardisation } \\
\text { principles } \\
\text { - Study on } \\
\text { potential for } \\
\text { common } \\
\text { components and } \\
\text { Pilot project } \\
\text { - Nordic Public } \\
\text { Cloud Tool Box }\end{array}$ & $\begin{array}{l}\text { - Common service } \\
\text { descriptions } \\
\text { - Common } \\
\text { framework } \\
\text { agreements } \\
\text { - Analysis of } \\
\text { possible attraction } \\
\text { of data centers }\end{array}$ & $\begin{array}{l}\text { Common } \\
\text { marketing } \\
\text { presentation } \\
\text { s on the } \\
\text { Nordic } \\
\text { region as a } \\
\text { standardised } \\
\text { and well- } \\
\text { functioning } \\
\text { area for data } \\
\text { centers }\end{array}$ \\
\hline $\begin{array}{l}\text { Annual } \\
\text { activities }\end{array}$ & & & & \\
\hline $\begin{array}{l}\text { - Monitoring } \\
\text { overview report }\end{array}$ & $\begin{array}{l}\text { Annual report on } \\
\text { public regulation } \\
\text { on Cloud } \\
\text { Computing }\end{array}$ & $\begin{array}{l}\text { - Annual update on } \\
\text { standardisation } \\
\text { initiatives and } \\
\text { guidelines }\end{array}$ & $\begin{array}{l}\text { - Overview of } \\
\text { framework } \\
\text { agreements }\end{array}$ & $\begin{array}{l}\text { - Annual status } \\
\text { report }\end{array}$ \\
\hline
\end{tabular}




\section{Introduction}

The public sector is facing a future with scarce resources and increasing pressure on budgets. The amount of people in the active workforce will decrease, and the amount of people in need for health care services, public education etc. will increase. As the demographics change, so will the expectations from citizens regarding the quality and quantity of services provided.

It is widely recognised that cloud computing can bring some advantages to public and private sector companies alike. Among these benefits are cost effectiveness, flexibility and green savings. Moreover, the fast prototyping, developing and testing of new solutions that cloud computing makes possible, enable an easier and faster process of innovation, i.e. developing new as well as existing services (Møberg, et al., 2010). Thus, the benefits of cloud computing have the potential to help solve the dilemma in the public sector: How to provide better services with fewer resources". There are, however, also barriers to a higher degree of use of cloud computing in the public sector. Among these are transition difficulties with existing applications, security and legal issues, loss of governance and risk of vendor lock-in. It is very difficult to make a clear business case because the "As-Is" situation and "To-Be" situation are not comparable.

Public administrations and public sector institutions in the Nordic countries have shown a beginning interest in cloud computing. However, the transition to cloud computing technology is a risk-based decision more so than a technology-based decision - and there are still barriers to embracing cloud computing, especially concerning standardisation, data security and legal issues. These barriers seem to have a greater effect on the public sectors of the Nordic countries than is the case in the US, where the "Cloud First" policy states a will to move public services to the cloud, as will be further described in this study.

Can cooperation between the Nordic countries help overcome these barriers, thus allowing the countries to reap the benefits of cloud computing at the national level?

The study at hand argues that there are at least two benefits of a Nordic cooperation on public sector cloud computing. Firstly, cloud computing has the potential to function as a driver for public innovation. Secondly, a Nordic cooperation will lead to faster realisation of the benefits of cloud computing at the national level. 


\section{Purpose}

This study is sponsored by the Nordic Council of Ministers with the purpose of increasing knowledge exchange and cooperation regarding the introduction of cloud computing in the public sector in the Nordic countries.

The purpose is to explore aspects of cloud computing where a coordinated effort between the Nordic countries may be to the advantage of the five countries at the national level. Furthermore, the study will examine within which aspects it will be rewarding and profitable to coordinate the efforts, and how the potential winnings by doing so are realised.

Finally, the purpose is to suggest areas of collaboration with relevance to cloud computing where a common Nordic coordinated effort will be more effective than efforts carried out at the national level and propose appropriate actions within these areas.

A working group ${ }^{1}$ under the auspices of the Nordic Council of Ministers has overseen the making of the study and contributed by providing insight and recommending interview informants for the study.

\section{Methodology}

The gathering of knowledge for this study has been conducted through qualitative research. Firstly, the authors have examined existing studies and articles. Secondly, a series of interviews have been conducted with market leading providers, researchers, market analysts, public IT strategists and procurers of cloud computing in the public sector ${ }^{2}$.

On the basis of the findings from the desk research and in cooperation with the working group, the authors have set up two initial hypotheses. These have been tested and further explored in the conducted interviews.

\footnotetext{
${ }^{1}$ See appendix A for further information on the working group

${ }^{2}$ An overview of the interviewed participants can be found in the appendix B.
} 


\section{What is cloud computing?}

\subsection{Definition}

Cloud computing is a collective term for pay-per-use IT services that are delivered over the internet. A cloud computing provider sells a service, e.g. office applications or business intelligence, to a procurer who can access the service through a web browser without installing or maintaining software on his own systems. Data is saved on a server in the "cloud", i.e. on a server in the cloud provider's data centre.

In other words, cloud computing enables the procurer to access ondemand, pay-per-use applications, services, storage, networks etc. without the preliminary investment in IT infrastructure and hardware and with the capability to quickly scale up or down.

\subsubsection{Cloud services}

The term cloud computing covers at least three different service models:

- Software as a Service (SaaS): Using an application without controlling the operating system, hardware or network infrastructure on which the application is running

- Platform as a Service (PaaS): Using a hosting environment for your applications without controlling the operating system, hardware or infrastructure on which the application is running

- Infrastructure as a Service (IaaS): Using computing resources on a virtual machine, such as processing power, storage and network without controlling the cloud infrastructure 


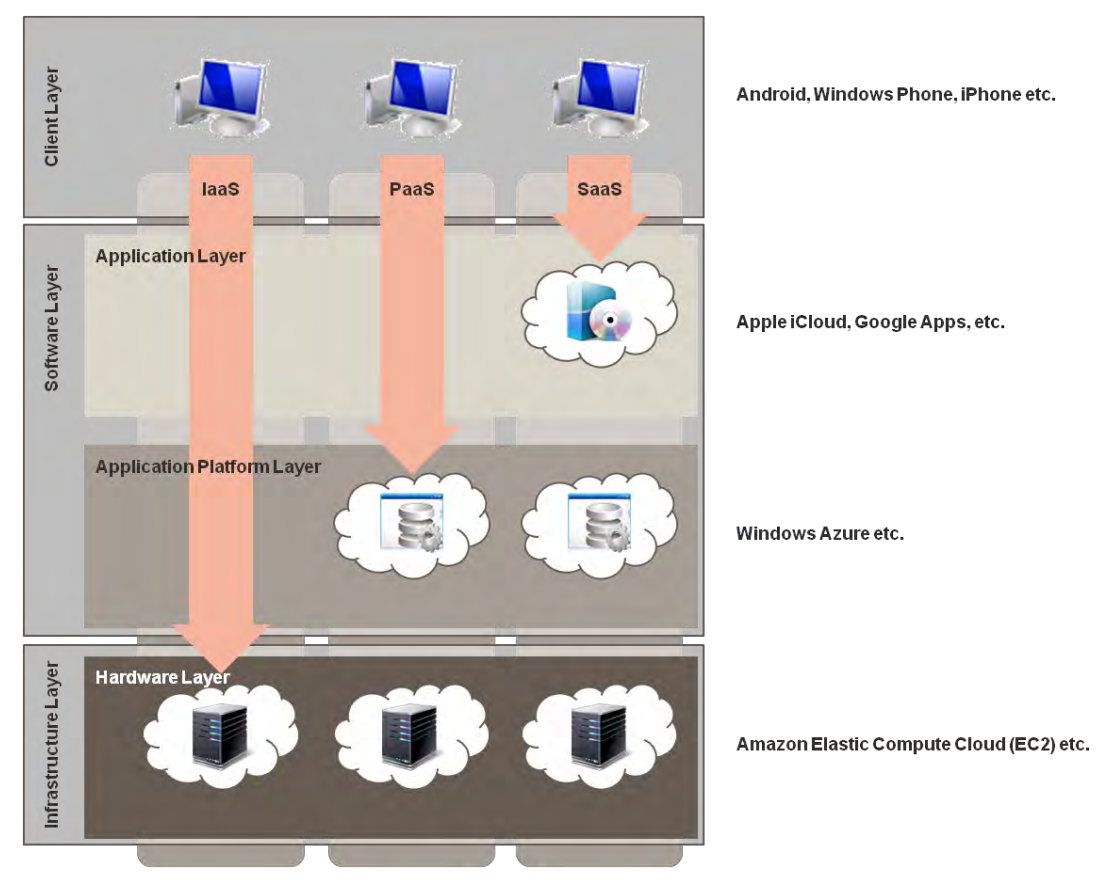

From http://ciscoschool.net/2010/03/25/clould-iaas-paas-saas-diagrams/

\subsubsection{Different types of clouds}

The NIST definition of cloud computing (NIST 2011) mentions four different deployment models:

- Private cloud: The cloud infrastructure is operated solely for a single organisation

- Community cloud: The cloud infrastructure is shared by several organisations

- Public cloud: The cloud infrastructure is owned by a company selling cloud services, and the cloud is made available to the general public or a large industry group

- Hybrid cloud: Combines two or more private, public or community clouds that remain unique entities, but enables data and application portability

The term cloud computing can have many connotations. This study uses the NIST definition of cloud computing (Grance \& Mell, 2011) and focuses on cloud computing usage in the public sector. The primary focus is on the deployment model "public cloud", but also includes "private cloud" and "hybrid cloud". 


\subsection{Benefits of cloud computing}

This section outlines the general potential benefits of cloud computing identified in the desk research and interviews. The extent to which the benefits can be realised will depend on several factors.

\subsubsection{Cost effectiveness - reducing capital expenditure}

With cloud computing, companies avoid costly asset acquisitions and reduce maintenance (Jeffery \& Neidecker-Lutz, 2010).

The on-demand nature of cloud computing implies that organisations only pay for services when they are required. Salem municipality expects a cost reduction by migration from Microsoft Office to Google Apps on EUR 1 million to 1.5 million in a three year timeframe. The reduction is based on reduced license fees and reduced need for IT service- and support (Zirn, 2011).

\section{Case: Municipality of Salem}

The municipality of Salem in Sweden has as a strategy to move all IT systems to cloud computing solutions before the end of 2015.

The municipality has chosen a Google Apps cloud computing solution as their office solution. Microsoft Office was used before the change. The solution has been in production for a year.

The primary reason for choosing a cloud computing solution was economy savings, but flexibility was also an important factor.

The municipality also obtained a higher quality of service. Especially, the users got roaming service and are now able to work independent of time and place with service and support 24/7.

The Data Inspection Board (DIB) in Sweden was interested in the manner in which the municipality protected personal information. DIB is now working on a set of rules for using cloud services and personal data. DIB expects the document to be finished this summer. DIB is also interested in the procedures for backup, logon and protection against unauthorised use of the services.

\subsubsection{On-demand self-service}

A consumer can procure computing capabilities such as server time and network storage as needed without requiring human interaction with the provider of each service. Of all service desk contact volume, as much as $40 \%$ could be solved through IT self-service, but only $5 \%$ of issues actually are solved by IT self-service, according to Gartner, Inc. (Guevara, Hall, \& Stegman, 2010). 


\subsubsection{Scalability}

Resources and services can be rapidly and elastically provisioned to quickly scale up and rapidly released to quickly scale down. To the consumer, the resources and services available often appear to be unlimited and can be purchased in any quantity at any time. Denmark was host for the World Climate conference in 2009, and IT services were built as a community cloud solution.

By choosing cloud services The Technical and Environmental Administration in The Copenhagen Municipality were able to deploy the solution fast, and very scalable. The scalability was important as an increasing load on the system was expected in the timeframe up to and under the conference (Teknik- og Miljøforvaltningen, 2010).

\subsubsection{Quality of service}

With cloud computing, resource usage can be monitored, controlled and reported, providing transparency for both the provider and consumer of the utilised service.

\subsubsection{Implementation speed}

The ease and speed with which organisations can get a solution up and running will accelerate the time required to bring new services to users. According to a Gartner case study, the 10th largest pharmaceutical company in the world Lilly (www.lilly.com) was reducing provisioning cycle time for a new server from 7.5 weeks to 3 minutes, a new collaboration environment from 8 weeks to 5 minutes and a 64-node Linux cluster from 12 weeks to 5 minutes (Cearley \& Phifer, 2010).

\subsubsection{Innovation}

Cloud computing is on-demand computing across technologies, business solutions and large ecosystems of providers and, therefore, reduces the implementation time for new solutions. The architecture of cloud computing facilitates services across systems, which makes new and innovative solutions possible.

The reduced time-to-market effect mentioned above along with the scalability that characterises cloud computing enables a quick and costeffective developing process. In other words, new solutions can be tested at a lower risk due to the fact that there is no need for large investments in infrastructure and hardware. Furthermore, cloud computing makes new types of solutions possible across organisational borders and systems. 


\subsubsection{Device and location independency}

Cloud computing are web-based services. This means that end-users can work and access applications and data from any device. Since the service provider has multiple locations, challenges related to proximity to the data centre are eliminated. Users can work from anywhere - home and office or on the road. This flexibility was one of the primary benefits for Salem Municipality.

\subsubsection{Green savings}

Greenpeace predicts that the global carbon emissions from computer use will double by 2020 (Greenpeace International, 2011).

Greenpeace also states, that datacenters that consolidate usage and power could conserve resources significantly. In an office environment, servers typically stay online $24 \times 7$. This may be necessary for the business - if workers need access remotely or software needs to run constantly - but it is extremely wasteful. Those servers are running at full power even if they are only needed for a small amount of processing. In a datacenter, every piece of the computer's processing power is used. Another aspect of the environmental friendliness of the datacenter is the power source. Most datacenters are equipped with extremely efficient energy infrastructures.

The green savings of cloud computing are:

- Reduced unnecessary power consumption

- Less hardware needed

- More effective cooling technologies due to scale

\subsubsection{Reliability and business continuity}

Data and user actions are mirrored in nearly real time across multiple worldwide distributed data centres. If one data centre becomes unavailable for some reason, the system is designed to instantly fall back to a secondary data centre with no user-visible interruption in service. Google Apps web interface will be operational and available to customers at least $99.9 \%$ of the time in any calendar month.

- (http://www.google.com/apps/intl/en/terms/sla.html), Amazon

EC2 promise $99.95 \%$ availability (http://aws.amazon.com/ec2/), and Microsoft Azure promise from $99.9 \%$ to $99.95 \%$ availability

- (http://www.microsoft.com/windowsazure/sla/)

The high availability delivered by the global cloud providers is difficult to deliver even by very large enterprises with state-of-the-art disaster recovery systems. 


\subsubsection{Efficiency}

There will not be the same need for internal support and service functions when services are moved to the cloud. For service orchestration, there will be a need for resources to manage cloud consumers, inventory (service catalogue), contract management security and business innovation.

\subsubsection{Security}

Despite the fact that security is often one of the biggest barriers to using cloud computing in the public sector, cloud computing actually has significant potential to improve information security. Security tools are cheaper when implemented at a larger scale and can, therefore, be implemented with higher quality and with extensive auditing. The interviews show that security and legal issues are priority concerns for many cloud customers. The achievement of improved security practices is a strong driver for cloud computing. The providers interviewed for the study (Google and Microsoft) have many ongoing initiatives to secure and minimise risk, even though they are not able to make specialised services and cannot manage national legal issues. The services are still delivered after the principle "one size fits all".

There is also a strong demand for external cloud service auditing. Auditing will be done in aspects such as operations, performance and security. This will drive the cloud providers to offer standardised, open interfaces to auditing service providers.

Cloud computing can also provide more cost-effective storage for logs, allowing more comprehensive logging without compromising performance.

\subsection{Cloud computing has the potential to act as a catalyst for public innovation}

This section investigates how the use of cloud computing can lead to a long term benefit of enhanced public innovation.

As mentioned in the introduction, the public sector is facing the challenge of having to deliver more with less without compromising the quality of services.

- Some services are no longer living up to the required quality standards

- New demands are emerging

- Traditional demands are diminishing

This constitutes a strong requirement for a high degree of innovation within the public sector going forward. 
This study argues that cloud computing has the potential to be a driver for public innovation. New technologies such as cloud computing offer the Nordic governments the ability to recognise and act upon new ideas, new operating methods and new ways of delivering services.

The employees and citizens are now online 24/7 to the effect that new services have to be developed very fast and with unpredictable lifetimes. The emerging technologies also mean that these services have to be accessed by different client types such as mobile apps, tablet computers, browsers etc.

Since June 2011, the citizens of five municipalities in Denmark have had the opportunity to be served outside their respective municipality's business hours. The five-municipal cooperation project "Online citizen service 24/7" extended the service offerings to local citizens and is also in collaboration with the City of Copenhagen.

http://www.furesoe.dk/Nyheder/2011/Oktober/OnlineBorgerbetjeningVok sevaerk.aspx.

\subsubsection{What is innovation?}

In order to comprehend the potential of cloud computing as a driver for innovation in the Nordic public sector, a general definition of the term "innovation" is needed.

\section{Definition}

Over time, numerous attempts have been made to define the term "innovation". In the Oslo Manual, OECD distinguishes between four types of innovations: product innovations, process innovations, marketing innovations and organisational innovations. Thus, innovation is:

“... the implementation of a new or significantly improved product (good or service), or process, a new marketing method, or a new organisational method in business practices, workplace organisation or external relations."

(OECD/Eurostat, 2005)

\section{Modus operandi of innovations}

In 1962, E. Rogers published his theory on "Diffusion of Innovation" explaining how, why and by what rate innovations (ideas and technologies) spread through members of a social system consisting of five stereotypes as shown in the figure (black line). 


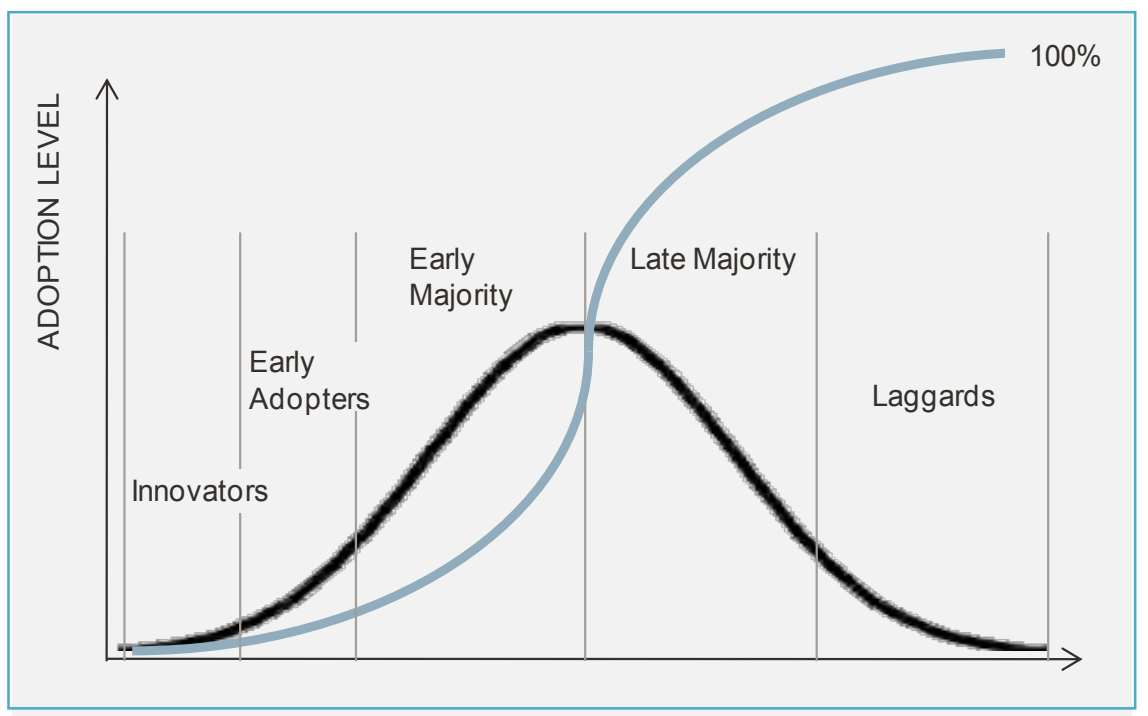

The blue line in the figure (the so-called S-curve) depicts how adoption towards a product, service, technology or organisation emerges over time. In addition to describing the evolution of a single technology or product, the S-curve can also be viewed on a macro scale as the evolution of the total capacity and yield with regard to leveraging new technologies, e.g. the innovation capability level of the public sector in the Nordic countries as a whole.

\section{Innovation and emerging technologies}

Private enterprises have a tendency to move along the S-curves faster than (most) public organisations. Even so, the difference between the private and the public sector is not as big as one might think when it comes to the dynamics of successful innovations. The major difference is that the public sector has one more dimension to manage: The way to the goal is driven by diverse political agendas.

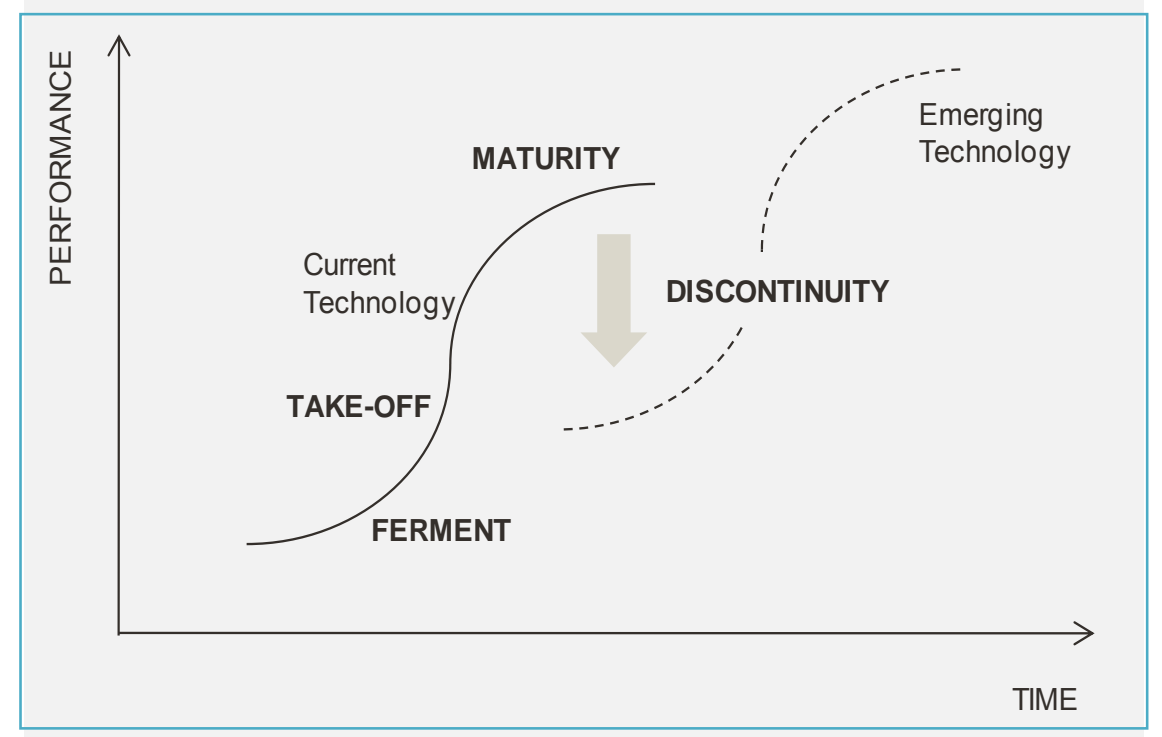


There are at least two innovation dynamics at play regarding innovation and emerging technologies. One type of innovation - called "disruptive innovation" - is illustrated in the figure below. It has to do with spotting a new technology and "jumping on" the new S-curve, hence, innovating products and/or services by way of the new technology. The other called "incremental innovation" - has to do with a continuous improvement loop constantly spinning off next iterations of existing products and services.

One of the most predominant factors affecting the chance of innovation is major changes that engage us in exploring uncharted territories. In the public sector, that would be disruptions such as the following:

- Shifts in political agendas

- Changes in demographics

- Economically challenging times

- Emerging technological possibilities

Such disruptions in an ecosystem - e.g. introducing a technology such as cloud computing - can potentially lead to new innovations, both incremental and disruptive.

There are several reasons to why organisations fail to identify emerging S-curves:

- Ignoring - or even fighting - disruptions and change rather than embracing it

- Risk adverseness leading to "zero tolerance" organisations, where people do not dare to challenge conventional wisdom or experiment with new ideas

- Lack of customer insights required to foresee the trends spurring changed needs

- Cultural inertia that hinders the ability to both manage existing business while at the same time investing in and driving the new business

- Not investing time and money in new technologies or the application of them

\section{Goals of public innovation}

As stated previously, the dynamics of successful innovation in the private versus the public sector are very similar: It all comes down to crossing the chasm from "early adopters" to "early majority" (Moore, 1999), i.e. the overall goal is to reach critical mass of adoption as fast as possible.

However, when it comes to specific goals, there is a major difference between the private and the public sector: Public organisations are political organisations, thus, the specific goals of innovation might be increased democracy and legitimacy - and not increased market share or improved profits. 
For public innovation to be considered a success, it has to create value in at least one of the following four dimensions:

- Increased efficiency in public processes and services

- Better quality in public services offered to enterprises and citizens

- Strengthened democracy, legitimacy and legal rights in the society

- Improved employee satisfaction through dynamic and attractive workplaces promoting recruitment and retention of employees (Danish Agency for Science, Technology, and Innovation, 2008)

\subsubsection{The role for cloud computing in innovating the public sector}

If innovation happens when disruptions occur, and we are forced to challenge our conventional wisdom as was illustrated in the previous section, then "How can an emerging technology such as cloud computing be a driver for public innovation?"

Gartner's Hype Cycle for Emerging Technologies examines the maturity of 1,900 technologies and trends in 89 areas. In the 2011 edition of the Hype Cycle, Gartner viewed cloud computing as being "at the peak of inflated expectations", i.e. beginning activity beyond early adopters. However, Software as a Service is viewed as being on the "slope of enlightenment", but still with 2-5 years until mainstream adoption (Gartner, 2011).

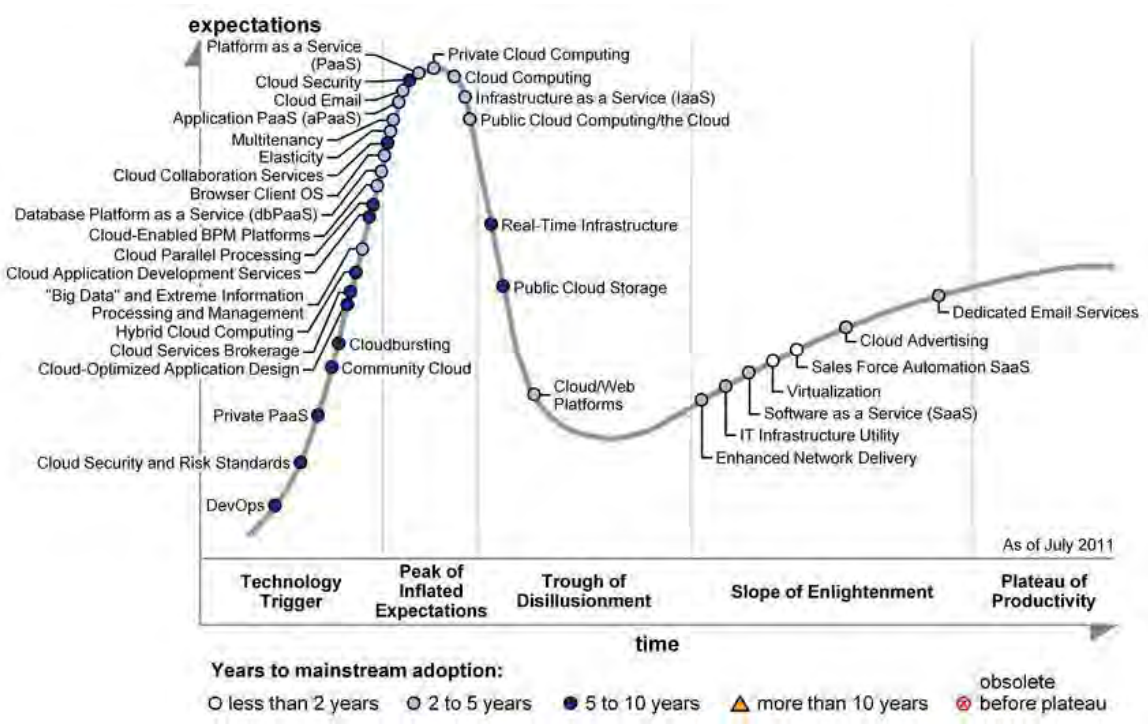

Gartner's Hype Cycle, Cloud Computing, 2011

In "The Big Switch" (2008), Nick Carr argues that cloud computing resembles the evolution of power generation and distribution. It used to be produced by the individual consumer making it a competitive differentiator; more power meant more goods (produced and) sold, i.e. higher 
revenue. Today, power in terms of electricity is a mere commodity being bought on a pay-per-use basis from central utilities; in the exact same way power in terms of storage and processing power is being made available through the business models based on cloud computing.

Just like the evolution in the energy market has changed business models, so has cloud computing. And there lies the disruptive dynamics of cloud computing. Just like new product and services models have emerged in the private sector (Google Apps, Amazon EC2, Microsoft Azure etc.), so will new business models, products and services emerge in the public sector. The technology encourages change in the way public organisations will operate and interact with citizens. The Finnish company Jobilinja is an example of a case where public data is used by a private company and is satisfying a market need.

The need for the Jobilinja service emerged from the dissatisfying user experience of the public vacancy service of the Ministry of Employment and the Economy in Finland. The vacancy information of the Ministry was opened, and Jobilinja built its own user interface to the database and provided a web service based on it (http://avointyopaikka.fi/). Thus, there is resource availability for services based on public information. Jobilinja estimated the total global size of online job listing services to be over $\$ 2$ billion and growing about $10 \%$ a year. The business model is based on advertisements.

This study cannot provide solid proof that cloud computing will drive public innovation. However, when assessing the ability of cloud computing as a technology to prepare the public sector for the future, there is much to be expected based on the fact that cloud computing is a collaborative technology, and that innovation is all about collaborating on getting from knowledge to value fast.

"Crossing the chasm" and jumping the S-curves of innovation diffusion not only require the relative attractiveness of the new alternative to outperform the existing technology - it also requires a certain level of organisational maturity.

If only a small fraction of the employees, politicians and citizens possesses the required skill set and insights to harness the benefits of cloud computing (or any other technology for that matter), crossing the chasm is prolonged. Implementing a technology platform to shorten the time from idea to value is all about increasing the awareness of what is possible and collaborating on realising the potential.

Because of cloud computing being a collaborative technology, projects and strategic initiatives in the public sector based on this will inevitably increase the level of co-creation both internally and externally, simply because the technology will force breaking down informational, procedural and organisational silos. 
The bottom line is that the closer the public sector gets to crossing the chasm of cloud computing, the more we can expect to see the true innovation potential of this technology. The public business models will change and evolve not only based on changes in demand and demographics, but more importantly also on the possibilities of the current available technologies combined with the capability of the organisations to utilise those possibilities.

\subsection{Barriers}

We have looked at some of the benefits of cloud computing, but the question remains: If there is so much to be gained by using cloud computing, why have we not seen a wider distribution of this technology in the Nordic public sectors? Below are some of the barriers identified in the research and interviews for the study.

\subsubsection{Transition to cloud computing requires thorough investigation}

Non-technological issues play a major role in realising cloud computing. Economic aspects have to be taken into account before the company can decide when, why and how to use which cloud system. The impact on the original infrastructure has to be investigated, and legal issues have to be clarified. This in particular covers issues related to intellectual property rights and data protection.

\subsubsection{Legal issues - data protection}

Cloud computing poses several data protection risks for cloud customers and providers. The Nordic authorities (as well as private enterprises) will have to make sure that personal data (sensitive as well as nonsensitive) is not handled in countries outside the EU/EES that do not comply with the Safe Harbor process (US companies) or similar. Otherwise, it will be necessary to make special agreements with the national regulatory authorities.

The Nordic authorities and companies will have to make sure that it is possible to monitor that the national security demands are met, that the demands of logging are met, and that storing and exchange of sensitive or non-sensitive personal data are encrypted.

However, the only difference between cloud computing and traditional hosting with respect to legal issues is the question of where (geographically) data is stored and the highly standardised terms of service agreements. 
Case: Municipality of Odense, Google Apps

Odense is the third largest municipality in Denmark and was planning migration of mail and schedule to cloud software service in Google Apps.

The Danish Data Protection Agency concluded that the treatment of personal information in Google Apps did not meet the requirements of the Danish Act on Processing of Personal Data.

The Danish Data Protection Agency referred to recommendations from The European Network and Information Security Agency (ENISA), "Benefits, risks and recommendations for information security", 9 November 2011, where the use of public clouds is not recommended for anything but the lowest assurance classes of data.

\subsubsection{Security}

With traditional IT, the customer has control of his own servers and applications. With the appearance of cloud computing, a shift happens where the customer will have to make sure that the provider can deliver the appropriate technical and organisational security. However, the challenges surrounding security are not essentially different from the issues in traditional hosting methods.

The company has to make a complete risk assessment to ensure that a solution offers the appropriate security level. The risk assessment may be based on standards for information security, e.g. ISO/IEC 27001. There is also information about the risk assessment in ENISA's publication "Cloud Computing: Benefits, Risks and Recommendations for Information Security."3

If these recommendations are followed by the national regulating authorities, it will be difficult to treat sensitive information (personal, financial) in a public cloud-based solution in the Nordic countries. As a minimum, it will require a thorough risk analysis and a very high degree of security in the solution, including compliance with the laws and regulations of the respective countries regarding treatment of sensitive data.

\subsubsection{Loss of governance}

By using cloud services, the client cedes control to the cloud provider on a number of issues, which may affect security. At the same time, service level agreements (SLAs) may not offer a commitment to provide such services on the part of the cloud provider, thus leaving a gap in security defences. 


\subsubsection{Lack of interoperability - vendor lock-in}

Contemporary cloud technologies have not been designed with interoperability in mind. This results in an inability to scale through business partnerships across cloud computing providers. In addition, it prevents small and medium-sized cloud infrastructure providers from entering the cloud provisioning market. Overall, this stifles competition and locks consumers to a single vendor.

\subsubsection{Existing business applications}

There are relatively few providers in each country that deliver the primary public business applications, which means that there is a great dependency on these providers and their vision - or lack of same - as to delivering these business applications in the cloud (as Software as a Service).

Furthermore, difficulties regarding integrating cloud solutions with existing applications, e.g. use of cloud computing with legacy systems or long existing value chains consisting of many applications within different areas where just a small proportion can be moved to the cloud, can be seen as a barrier.

\subsection{Enablers}

There is no doubt that cloud computing offers the potential to deliver significant benefits to the organisations who adopt this technology - not only seen from a pure economical point of view, but also in terms of agility and innovation.

However, success is not to be taken for granted; certain factors are imperative for achieving the desired effects from a cloud computing initiative.

First of all: Developing a cloud computing strategy and making sure it is well anchored. The strategy should disclose the current state in terms of drivers and barriers across the (political) landscape with regard to ICT maturity, infrastructure and (political) needs.

Secondly: Articulating and communicating the "whys" and desired effects of your initiative. Making it a realistic and relevant "burning platform" for change. 


\section{Present state - use and distribution of cloud computing}

\subsection{The Nordic countries}

The interviews conducted for this study show that at least parts of the public sectors in the Nordic countries have visions and an active agenda on cloud computing usage. However, this holds true more so for Sweden, Denmark, Norway and Finland than Iceland. The visions - as well as the experienced barriers - share common features.

At the macro level, the Nordic countries have similar visions for the welfare state and a set of common challenges. There is a demand in the whole region for more effective IT support of the public sector and delivery of fast and effective services to enterprises, other public institutions and citizens.

As we will explore in more detail below, the Nordic public sectors are in a good position to increase the use of cloud computing and realise the potential benefits regarding cost effectiveness and increased flexibility.

\subsubsection{IT maturity in the Nordic countries}

The Nordic countries are ranked highly in different e-readiness overviews.

Sweden takes the first place in the World Economic Forum and INSEAD's Networked Readiness Index (Dutta \& Mia, 2011), because of the country's favourable climate for technological innovation and adoption and penetration of new technologies. For example, more than $90 \%$ of the population uses the internet on a regular basis. The survey, which evaluates the countries' e-readiness on three components (individual readiness, business readiness and government readiness), ranks Finland, Denmark, Norway and Iceland all within the top 20 on the Network Readiness Index (NRI)4. 
“... the Nordic countries are still among the most successful in the world in fully integrating new technologies in their competitiveness strategies and using them as a crucial lever for long-term growth, as noted above. Their prowess is based on some common enabling features. In particular, they all display a very innovation-friendly environment, with transparent and conducive regulations and top-class educational and research systems working closely with the industry, together with a strong innovation culture society-wise. Moreover, a consistent focus on innovation and ICT diffusion in the government agenda over the years has resulted in remarkably high ICT penetration rates and in the emergence of global players in high-tech and innovative products."

(Dutta \& Mia, 2011, p. 19).

The Digital Economy Rankings survey (The Economist Intelligence Unit, 2010) ranks countries on the basis of their ability to maximise the use of ICT in the years ahead. This survey also ranks Sweden as number one, and the Nordic countries that are covered ${ }^{5}$ all rank within the top 10 in the survey ${ }^{6}$. This means that Sweden in particular and the Nordic countires in general share the ability to absorb information and communications technology (ICT) and the ability to use it for economic and social benefit.

\subsubsection{Nordic innovation capabilities are world leading}

According to the Innovation for Development Report 2010-2011, the understanding of what drives national prosperity has evolved over time. Recently, the innovation excellence of a country - i.e. its industries, researchers, developers, creative thinkers, enlightened politicians, managers and clusters - has been identified as perhaps one of the most important modern engines of productivity and growth.

${ }^{5}$ Iceland is not covered by the study.

${ }^{6}$ Sweden, Denmark, Finland and Norway are ranked at 1st, 2nd, 4th, and 6th respectively. 


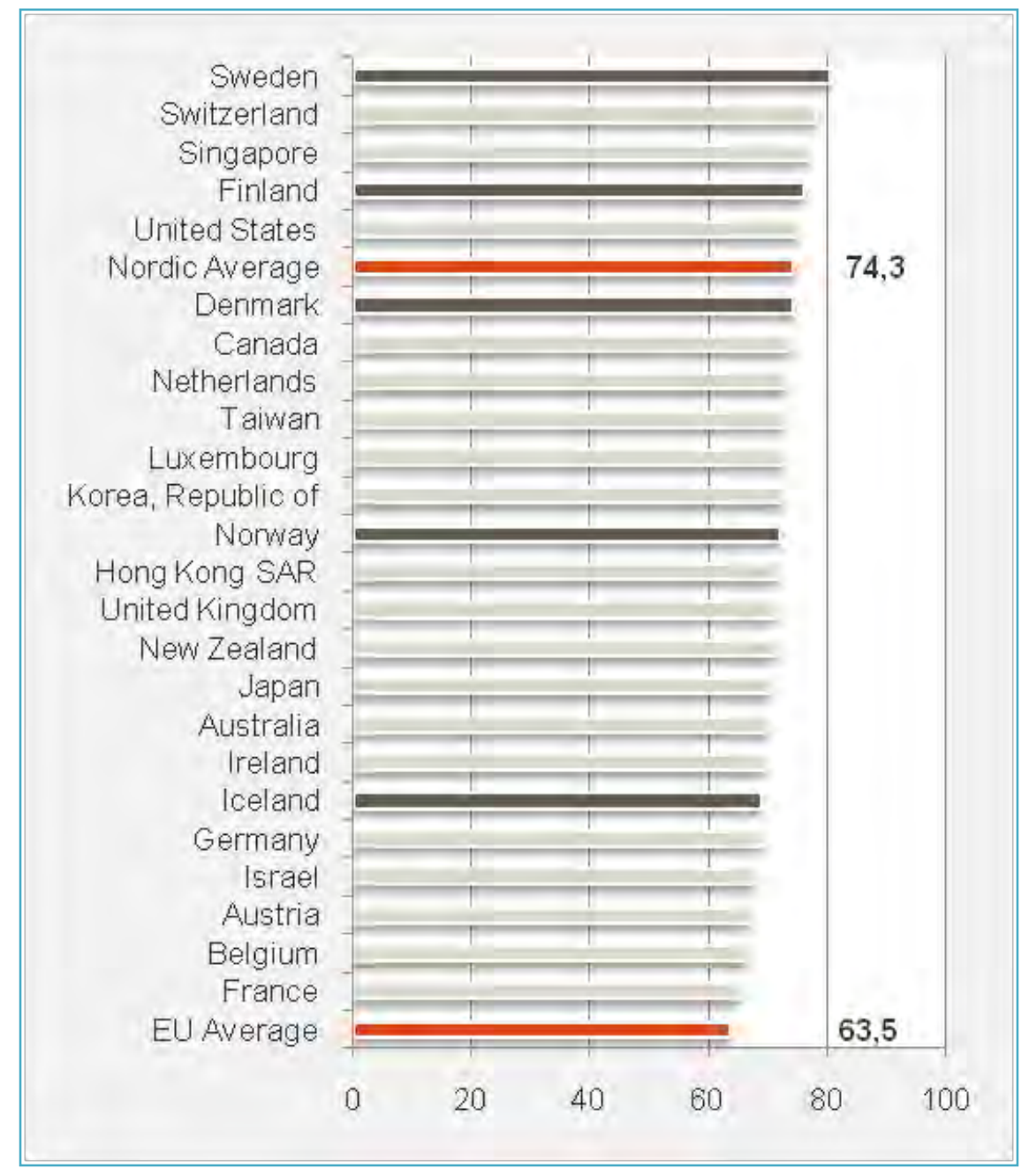

The report discusses the role of innovation in promoting economic and social development. In particular, it features the Innovation Capacity Index (ICI), and it not only ranks each of the individual Nordic countries in the top 20, but more importantly places the Nordic region as a whole in a world leading position (The Innovation for Development Report 2010-2011, 2010).

In short, the common denominators for the impressive Nordic scores are very efficient government services, high educational levels and broad adoption and use of information and communication technologies (ICT) - all based on a long history of strong democratic values, supporting a very similar welfare model. Anchored in empirical observations, the authors of the report argue that democracies tend to outperform authoritarian regimes when it comes to encouraging the creation of innovation-friendly environments.

This emphasises the vast potential of the Nordic countries in respect of technology-driven innovation. 


\section{Example of Nordic collaboration on innovation: The Nordplus programme}

Nordplus is the Nordic Council of Ministers' largest education programme in the field of lifelong learning. It consists of the Nordplus Framework Programme[1] which offers financial support to a variety of educational cooperation between partners in the area of lifelong learning from the eight participating countries in the Baltic and Nordic regions. Besides promoting Nordic languages and culture and mutual NordicBaltic linguistic and cultural understanding, the main aims of the programme are:

- To contribute to the development of quality and innovation in the educational systems for life-long learning in the participating countries by means of educational cooperation, development projects, exchanges and networking

- To support, develop, draw benefit from and spread innovative products and processes in education through systematic exchange of experiences and best practice

According to an evaluation of the Nordplus programme (Stensaker, Borden, Musial \& Schwach, 2001) the most important objective of the programme is strengthening Nordic languages and culture, innovation, quality and cooperation. The evaluation states that "these objectives are achieved by means of the activities funded by the programmes: mobility, networking and projects. In addition, Nordplus is a Nordic initiative, so equal participation and benefits are key to its long-term legitimacy."

\subsubsection{Distribution and use of cloud computing}

The different national analyses of the distribution and use of cloud computing show a great variation in the number or percentage of use of cloud computing, which makes it difficult to compare the analyses - both nationally and across borders. Cloud computing is a broad term that is understood at different levels by different companies and users.

The research for the study at hand shows that companies and public administrations in the Nordic countries have shown interest in cloud computing and are using it to some extent. However, this is true to a much lesser extent in Iceland and can only be documented as a percentage of uptakes of cloud computing in the public sector in the case of Denmark, Norway and Sweden.

According to Statistics Denmark, $37 \%$ of public companies in Denmark use cloud computing solutions to a higher or lower degree (Danmarks Statistik, 2010). A recent Danish study shows a rapid adoption of cloud computing to more than $35 \%$ in both the public and private sector (Møberg, et al., 2010).

A slightly higher percentage is found in Sweden, where Kammarkollegiet mentions that $42 \%$ of public sector organisations use cloud computing solutions to a higher or lower degree (Kammarkollegiet, 2010). 
According to IKT-Norge, trade organisation for ICT companies in Norway, only $10 \%$ of public companies in Norway were using cloud computing in 2010 (Hoff, 2010).

The study provides no figures on adoption of cloud computing in Iceland or Finland. The motivation for cloud computing usage in Iceland seems low, as the expected benefits do not outweigh the transitions cost and risk associated with using public cloud services.

The visionary focus of cloud computing usage would arguably use the public cloud deployment model, as it has the greatest potential when it comes to the benefits of cloud computing. However, the interviews show that there is a more pragmatic agenda in the Nordic public sectors which focuses on private clouds. There is a possible evolution from private over hybrid to public clouds. The question is whether a Nordic cooperation can be a stepping stone towards using public clouds?

\subsubsection{National enablers and barriers}

Below are some of the national enablers and barriers identified in the research.

\section{Nordic Enablers}

The conditions for fast adoption of cloud computing are already in place in the Nordic countries, e.g. telecom infrastructure, IT infrastructure and visions of use of IT and IT services in the public sector (The Economist Intelligence Unit, 2010).

Another enabler towards cloud computing is the green power (hydroelectric power and geothermal energy) and cooling at an attractive cost that can be provided by e.g. the Icelandic climate and environment. In the Nordic countries - especially where low-cost "green" electricity and natural cooling due to the cold climate are at hand - a relatively big part of the interest in cloud computing is concentrated around building data centres to be used for cloud computing services. Since the cost of electric power is one of the largest operating costs for data centres, keeping these costs down will be vital for the success of cloud computing providers.

The same argument is held by Norway, Finland, Sweden and Denmark (by way of Greenland). Cloud computing providers seem to find the prospect interesting. Google has built a data centre in Finland, Microsoft has been in dialogue with Greenland about a data centre establishment, and Facebook builds their new data centre in Luleå, Sweden.

Another enabler in Iceland are the high speed data lines connecting the two continents (the US and EU). But there are also challenges in data centre offerings. Challenges can be national taxes or legal requirements. 


\section{Barriers}

In the interviews for the study, the informants in the five countries all mention legal issues surrounding security and personal data as a great barrier to using cloud computing.

In the case of the municipality of Salem in Sweden, the Swedish Data Inspection Board 28 September 2011 stated that the standard Google agreement used between Salem and Google does not fulfil the legal requirements in the Swedish Personal Data Act (Datainspektionen, 2011). The conclusion is comparable to preliminary conclusions in the Narvik case in Norway (Digi.no, 2011) and in the Odense case in Denmark (Datatilsynet, 2010).

The laws on personal data in the Nordic countries state that personal information can only be transferred to countries in the EU/EES, as long as a proper security level is maintained. Data can also be transferred to some countries outside EU/EES if the country agrees to meet EU standards under the directive's Safe Harbor principles.

The public companys has to make sure that cloud service providers have the security and infrastructure in place for the company to live up to security level and national laws, and the governance can be very difficult because of the distributed nature of cloud computing.

As a means to overcoming this barrier, the National IT and Telecom Agency in Denmark has published a guide for legal aspects of cloud computing usage, including an evaluation of cloud services against the Personal Data Act. Many of the aspects in the guide are related to the lack of a clear legislation model regarding jurisdiction over the hosted data, its distribution in other countries etc. (IT \& Telestyrelsen, 2011).

The Nordic countries are comparable concerning laws for securing personal data. Legal issues with cloud computing are comparable to legal issues for normal IT hosting. The difference is that global providers (Google, Amazon, Microsoft etc.) are not able to physical locate data, and localisation is an essential legal requirement that all Nordic countries must fulfil.

\subsubsection{Political climate, strategy and decisions}

Economic and demographic challenges place demands on the public sectors to be more efficient. These demands are reflected in the national public IT strategies of the respective countries.

The requirements for future public services in Sweden are described in the strategy for eGovernment, published in October 2009 by the Swedish eGovernment Delegation. 


\begin{abstract}
"The perspective of the Action Plan of 2008 is user-centric: to make it simple for citizens and companies to handle their contacts with government and gain access to public services. Government digital information and data should also be made available for further use by third party actors with the motive that better access to public information supports economic development and makes everyday life easier for citizens and business."
\end{abstract}

(Nordfors, Ericson, Lindell, \& Lapidus, 2009)

The Finnish Government adopted a report entitled "Productive and Innovative Finland - Digital agenda for the years 2011-2020", which was submitted to the Parliament 26 November 2010. The report mentions cloud computing among other initiatives (Finnish Government, 2010).

Inspired by Sweden and Finland, Norway is working on a national digital agenda based on the Digital Agenda for Europe. The Norwegian Minister of Government Administration, Reform and Church Affairs says:

"We must make sure that Norway has an effective and user-oriented public sector that takes advantage of the potential of IT." (Aasrud, 2011, our translation)

The Icelandic e-strategy, "Iceland the e-Nation", focuses on efficiency, e.g. by simpler public administration, service, e.g. by a high degree and quality of self-service, and progress, e.g. by innovation, research and education (Prime Minister's Office, 2008).

Denmark has a shared digital strategy. With the strategy, the government, municipalities and regions want to increase the use of digital services to renew the public sector and make it more effective (Regeringen / KL / Danske regioner, 2011).

In their 2011 programme "Digitale veje til vækst" (digital paths to growth), the former Danish Ministry of Science, Technology and Innovation published a set of actions for overcoming the barriers to using cloud computing. The ministry's goal is to make it easier to make full use of the benefits of ICT with cloud computing.

The focus is on composing methods for better security and privacy and publishing guidelines for public authorities and private companies.

In cooperation with the universities, the ministry will function as a laboratory and communicate their experience to the public sector.

The ministry also suggests that a Nordic cooperation on cloud computing for the public sector could be established, e.g. through joint demands to the suppliers, a common framework for cloud services regarding security and legal issues.

Along with the demands of an efficient public sector are other demands such as reduced $\mathrm{CO}^{2}$ emission. IDC has investigated the potential server and data centre $\mathrm{CO}^{2}$ savings in Denmark for the Danish High Speed Committee and the Danish National IT and Telecom Agency (Elbak \& Andersen, 2009). 
The conclusion is that the power consumption by servers and data centres in Denmark in 2009 is estimated at $864 \mathrm{GWh}$ per year. In cost, this equals EUR 130 Million assuming an average price of 0.16 EU$\mathrm{RO} / \mathrm{KWh}$ or a total $\mathrm{CO}^{2}$ emission of 381,000 tonnes per year. Server and data centre power consumption as well as corresponding $\mathrm{CO}^{2}$ emission will increase by $34 \%$ by 2013 compared to today. The public sector in Denmark (including local, regional and national governments) accounts for about $24 \%$ of server and data centre power consumption (including the public sector's use of private data centres).

\subsection{Europe}

\subsubsection{IT maturity}

According to the INSEAD Networked Readiness Index, Europe as a whole displays "remarkable levels of ICT readiness" (Dutta \& Mia, 2011). More than $60 \%$ of households and $90 \%$ of enterprises are connected to broadband, even if deployment of next generation access is only beginning. The good results are - among other factors - due to a favourable regulatory environment.

\subsubsection{Political climate, strategy and decisions}

The European Commission has collected views from citizens, businesses, public administrations and other interested parties on how to fully benefit from cloud computing. The online public consultation ran until 31 August 2011. Responses will feed into the preparation of a European cloud computing strategy that the Commission will present in 2012.

The commission is convinced that companies can drastically reduce information technology costs, help governments supply services at a lower cost and save energy by making more efficient use of hardware.

Cloud services are expected to generate revenues of almost EUR 35 billion in Europe by 2014 (European Grid Infrastructure, 2011). Promoting the right conditions for citizens and businesses to best benefit from this technical development is one of the actions foreseen by the Digital Agenda for Europe.

The survey has focus on the following issues:

- Data protection and liability questions, in particular in cross-border situations

- Legal and technical barriers that can slow down the development of cloud computing in Europe

- Standardisation and interoperability solutions 
- Uptake of cloud services, in particular by SMEs (small and mediumsized enterprises)

- Ways to promote research and innovation in cloud computing

The strategy will aim to clarify the legal conditions for the take-up of cloud computing in Europe, stimulate the development of a competitive European cloud industry and market and facilitate the roll-out of innovative cloud computing services for citizens and businesses.

The delivery strategy for a government cloud (G-Cloud) in the UK will be published in October 2011. The purpose of G-Cloud is to follow in the steps of the US' "Cloud First" policy.

\subsection{The United States}

\subsubsection{IT maturity}

The US is ranked number 5 on the NRI (Dutta \& Mia, 2011). The US is evaluated very positively as regards ICT usage by government, enterprises and academia. The country ranks 2 nd with regard to the quality of the government's internet services and 6th regarding the quality of interaction between the government and citizens using new technologies.

\subsubsection{Distribution and use of cloud computing}

The government institutions in the US are able to use cloud computing in government clouds from providers such as Amazon (AWS GovCloud) and Google (Google Apps for Government). A survey (from Information Week Government) of federal IT pros' cloud plans reveals that $29 \%$ of agencies use cloud computing and another $29 \%$ expect to do so within 12 months (Biddick, 2011). 


\section{Example of Nordic collaboration on innovation: The Nordplus programme}

Nordplus is the Nordic Council of Ministers' largest education programme in the field of lifelong learning. It consists of the Nordplus Framework Programme[1] which offers financial support to a variety of educational cooperation between partners in the area of lifelong learning from the eight participating countries in the Baltic and Nordic regions. Besides promoting Nordic languages and culture and mutual NordicBaltic linguistic and cultural understanding, the main aims of the programme are:

- To contribute to the development of quality and innovation in the educational systems for life-long learning in the participating countries by means of educational cooperation, development projects, exchanges and networking

- To support, develop, draw benefit from and spread innovative products and processes in education through systematic exchange of experiences and best practice

According to an evaluation of the Nordplus programme (Stensaker, Borden, Musial \& Schwach, 2001) the most important objective of the programme is strengthening Nordic languages and culture, innovation, quality and cooperation. The evaluation states that "these objectives are achieved by means of the activities funded by the programmes: mobility, networking and projects. In addition, Nordplus is a Nordic initiative, so equal participation and benefits are key to its long-term legitimacy."

\section{Case: "The Department of Energy"}

The Department of Energy is evaluating the cost and efficiencies resulting from leveraging cloud computing solution across the enterprise to support business and scientific services. The Lawrence Berkeley Lab has deployed over 5,000 mailboxes on Google Federal Premiere Apps, and they are now evaluating the use of Amazon Elastic Compute Cloud (EC2) to handle excess capacity for computers during peak demand. The lab estimates that they will save $\$ 1.5$ million over the next five years in hardware, software and labour costs from the deployments they have made (McClure, 2010). 


\subsubsection{Political climate, strategy and decisions}

Vivek Kundra, US Chief Information Officer, published the plan "25 Point Implementation Plan to Reform Federal Information Technology Management" 9 December 2010 (Kundra, 2010).

Some highlights of the implementation plan include firstly a shift to a "Cloud First" policy.

The Cloud First policy implies that each agency will identify three "must- move" services within three months and move one of those services to the cloud within 12 months and the remaining two within 18 months.

Secondly, the number of federal data centres is to be reduced by at least 800 by 2015 . Thirdly, major IT programmes must live up to these criteria:

- Have a dedicated programme manager and a fully staffed integrated programme team

- Use a modular approach with usable functionality delivered every six months

- Use specialised IT acquisition professionals 



\section{Why Nordic cooperation on public sector cloud computing?}

We have looked at some of the benefits of cloud computing and the barriers towards reaching these benefits. We have further seen that the Nordic countries have the right conditions for broadening the uptake of cloud computing in the public sector. In a broader perspective, the European Commission is working on a cloud computing strategy, while the United States, with the Cloud First initiative has set a standard for the use of cloud computing in the public sector.

One question remains though: What can be gained by Nordic cooperation on cloud computing? This part of the study will address two of the most predominant enablers of cloud computing in the public sector:

- Radical demographic and economical challenges driving a profound need for innovating in the public sector

- Faster realisation of benefits through increased flexibility, fuelled by Nordic cooperation

\subsection{Cooperation can lead to faster realisation of potential}

This study argues that cooperation between the Nordic countries can help overcome the barriers slowing down the benefit realisation from cloud computing. The most successful public benefit realisation initiatives within IT today are consolidating administrative areas, user-driven solutions, cross-sector focus and spillover and private-public cooperation (Møberg, et al., 2010). Nordic cooperation focusing on the right things together with successful implementation of common cloud initiatives can give these successful areas more potential. Benefit realisation can happen faster with Nordic cooperation than with cooperation between a single Nordic country and countries outside the Nordic region. Furthermore, Nordic cooperation can bring economy of scale into the solutions.

This study shows that the Nordic countries are challenged by the common barriers, that prevent the full realisation of the benefits of cloud computing. However, the Nordic countries also have a strong 
common foundation with regard to e-readiness, innovation capabilities, political systems etc. The similarities and "good neighbour" atmosphere in the Nordic region will can make benefit realisation of cloud computing happen faster and shorten the amount of effort put into overcoming the barriers as shown in the figure.

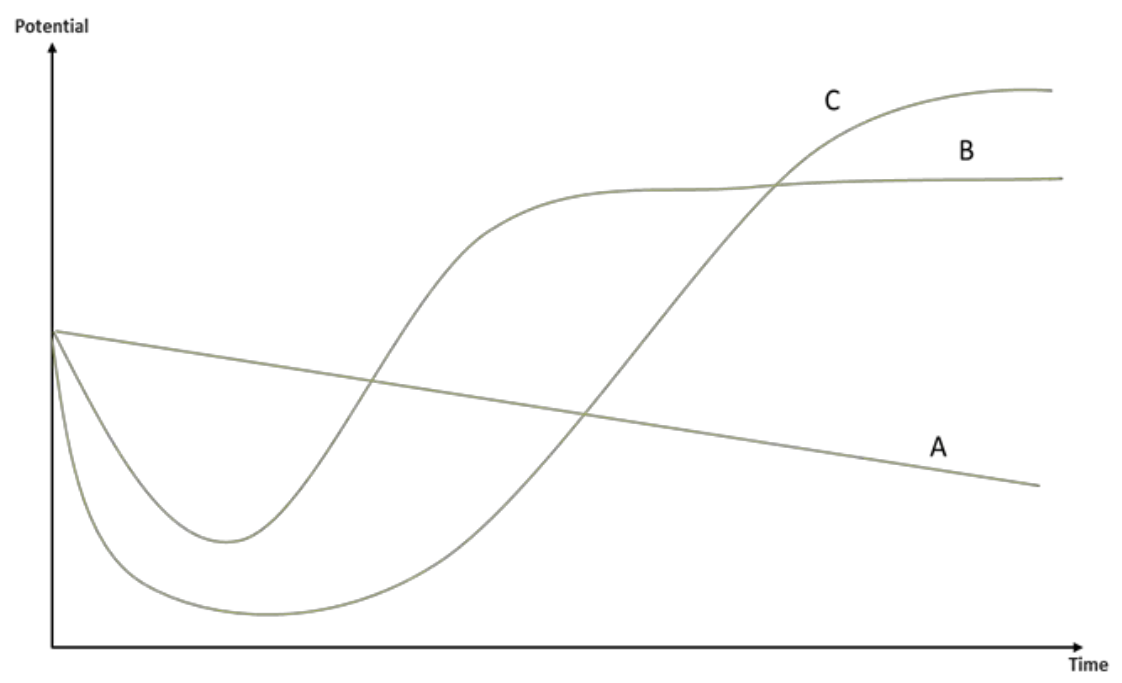

The potential in continued business as usual $(A)$ decreases in the years to come. The increasing demands and use of technology challenges the infrastructure and IT organisations, resulting in cost efficiency getting worse every day. $30 \%$ of Danish companies realise that the cost of application maintenance from 2009-2010 has increased Most companies are using a lot of effort in optimising the maintenance cost to free more economy and power to innovation and strategic project implementation (IT i Praksis 2010, 42). If the Nordic countries cooperate on knowledge sharing and common initiatives on cloud computing, the potential and benefits can be realised faster $(B)$. On the other hand, the potential in a wider cooperation on cloud computing - e.g. in the $\mathrm{EU}$ - is even greater, since this can generate economy of scale and flexibility that makes benefit realisation bigger than what can be gained from Nordic cooperation $(C)$. However, the barriers of getting a successful cooperation on cloud in place will take longer time to overcome than in the example of the Nordic region. To exemplify, to achieve legal and regulatory cooperation is more difficult and more time-consuming in a broader context across the world than in the Nordic region.

These hypotheses indicate that Nordic cooperation can overcome these barriers and realise the benefits earlier. 


\subsubsection{Knowledge sharing can help overcoming non- technical barriers}

Knowledge sharing on cloud computing such as sharing guidelines, case studies, framework contracts, analyses and statistics can be an enabler for public sector institutions to help overcome technical as well as nontechnical issues. This could be in the form of a shared information portal for the Nordic region. Knowledge sharing could be an advantage for all countries on the following issues:

- Strategies for reducing operation cost

- Developing effective strategies on how to address global pressure to reduce carbon emissions

- Analyse legal and regulatory issues

- Best practices and successful stories on how to deal with current trend and challenges

- Addressing the difficulties in attracting experts and highly skilled employees to the Nordic region

\subsubsection{A common stand on security and legal issues}

As has been shown earlier in this report, the general data protection regulation can be a great barrier for the use of cloud computing.

The global providers of cloud computing services provide standard products regulated by standard agreements. This does not match very well with the specific data protection regulation in the different EU member states.

The directive on the protection of personal data ${ }^{7}$ has been adopted in all the Nordic countries, but with slight differences to the implementation For example Denmark has issued an executive order on security, which applies when Danish public autorithies process personal data.

Currently, the global cloud computing providers use standard agreements to deliver their services as "one size fits all". This means that the public authorities in the Nordic countries have major challenges complying with the demands of the national regulation on data protection, when entering into agreements with these providers. It is currently unresolved, whether the global public cloud computing providers can comply with the legal barriers of the Nordic countries or not.

The data protection agencies of the Nordic countries have each emphasised the following regulatory issues regarding cloud computing:

${ }^{7}$ Directive 95/46/EC 


\section{The risk analysis}

When assessing cloud computing services, the data protection agencies generally require a more thorough risk analysis than required from conventional hosting services.

\section{The contract between the data controller and the data processor}

The data protection agencies have pointed out a number of legal issues which should be adressed in the contract ${ }^{8}$. These issues include:

- That the data processor must only act on instructions from the data controller

- That the agreement must be governed by the national data protection regulation (applicable law)

- That an adequate level of data security in accordance with the relevant data protection regulation must be ensured

- Measures of controlling compliance with the data security demands.

- The actual location of the data

- Deletion of data

As shown above, the proctetion agencies troughout the Nordic countries share a few key points regarding the use of cloud computing in the public sector. Nordic cloud computing providers ${ }^{9}$ can take advantage of this because they can deliver cloud computing services compliant with Nordic national data protection regulation in the same way as Amazon and Google have complied with the data protection regulation in the United States.

But for the public sector institutions in the Nordic countries, there is a big difference in the benefits from economy of scale, and there would be potential savings in Nordic cooperation that could streamline the legal demands for the public use of cloud computing.

The legal systems are very similar in the Nordic region, and the mindset is more common here, than among many other neighbouring countries. In spite of the fact that the national regulation of this area differs slightly in the Nordic countries and there are barriers to overcome regarding the EU/non-EU membership, the overall perspective on this is, that these barriers can be overcome faster when cooperating at a Nordic level.

\footnotetext{
8http://www.datatilsynet.no/upload/Dokumenter/veiledere/Veileder\%20Cloud\%20Computing\%20ver\%2 01.0_med_forside.pdf

http://www.datainspektionen.se/Documents/beslut/2011-09-30-salems-kommun.pdf http://www.datatilsynet.dk/afgoerelser/seneste-afgoerelser/artikel/behandling-af-foelsommepersonoplysninger-i-online-kontorpakke/

${ }_{9}$ Providers with focus on cloud computing to the public sector in one or more countries in the Nordic region are companies such as ErgoGroup, CSC, Logica, Tietor and Atea. An example of a national provider is KMD (Danish IT company providing IT services to local government, central government, regional and private customers) which is offering a national cloud computing platform based on Microsoft Azure technologies.
} 


\subsubsection{The Nordic region can gain buying power}

The public sector in the Nordic region is dominated by large suppliers with extensive control and bargaining power. Starting up a Nordic cooperation setup on cloud computing will put a pressure on the vendors of cloud solutions to incorporate interoperability because of an increased demand from the Nordic region as a whole. The economy of scale of the Nordic cooperation will open up the market for medium-size vendors. Furthermore, harmonised procurement processes and standards will help attract providers to the Nordic market. These types of initiatives will also make it easier for the Nordic countries to adopt cloud computing in the public sector. The Nordic countries can benefit from collective negotiations with suppliers as requirements and demands are alike.

\subsubsection{Procurement processes}

With common Nordic demands and requirements, knowledge and tool sharing could be an advantage for the Nordic countries. There is a framework agreement on ASP/cloud computing in Denmark from SKI. Statens inköpscentral at Kammarkollegiet in Sweden use the existing framework agreement "E-förvaltningsstödjande tjänster 2010" for highly specialized cloud services. Statens inköpscentral is also about to create framework agreements on specific cloud services, and the first framework agreement targets office solutions.

Cloud computing is still an immature market - there are still few providers and few case studies. Because of security and legal issues, cloud consumers must ensure that the data protection requirements are included in a binding contract with the cloud provider. This can be achieved by means of individually negotiated clauses in the contract or through the security and data protection policy of the provider. These clauses are comparable in the Nordic countries, and there could be reason for both cloud providers and consumers (the Nordic Region) to negotiate these clauses collectively.

Furthermore, transparent pricing is a common requirement for the Nordic countries, and standard price models could be created to achieve this. Cloud computing providers do not describe terms for pricing, SLAs and user policies in the main contract, but on separate web pages. The providers often maintain rights to change the content of those web pages at any time. This can be problematic as the new terms may no longer meet the requirements of the cloud consumer. It is also very difficult to compare prices and terms because of lack of standards in that area. 


\subsubsection{The Nordic region can define common demands and standards}

Because cloud computing is a new technology, the formal standards are not yet ready.

The Nordic countries can accelerate the development of standards and increase the level of confidence in cloud computing adoption in the interim period before cloud computing standards are formalised. The Nordic countries could review existing standards for relevance and identify future standards.

The following standards could be determined in the Nordic community:

- Standards for federated identity

- Data exchange among clouds

- Standards for moving applications between cloud platforms

- Standardised output for monitoring, auditing and billing

- Standards for application development interfaces, protocols etc.

- Independent standards for policies and governance

- Standards for service level agreements

It is furthermore assumed that the Nordic public procurers have common requirements.

\subsubsection{Attracting data centres}

The Nordic region has unique conditions for data centres because of low-cost green power, sufficient network infrastructure, high level IT workforce and similar procurement models.

Good cooperation experience exists in the Nordic Data Grid Facility (NDGF), according to Brian Vinter, Niels Bohr Institute. The motivation for NDGF was to ensure that researchers in the Nordic countries could create and participate in computational challenges of scope and size unreachable for the national research groups alone. NDGF is a production grid facility that leverages existing, national computational resources and grid infrastructures and is on certain parts comparable with the challenges in cloud computing.

Knowledge sharing for staying competitive in the area of data centre offerings could be an advantage for all countries on the following:

- Strategies for reducing operation cost

- Developing effective strategies on how to address global pressure to reduce carbon emissions

- Analyse legal and regulatory issues

- Best practices and successful stories on how to to face current trend and challenges 
- Addressing the difficulties in attracting experts and highly skilled employees to the Nordic region

\subsection{7 (Public) innovation}

Clearly, the Nordic countries have a unique position when it comes to technology-driven innovation, and cloud computing will indirectly increase collaboration and co-creation. The speed of technological evolution is ever increasing, and very few public organisations have the capacity or the capability to stay ahead and on top of things. This makes the ability to produce, collect and share best practices in a systematic way an imperative for the public sectors moving forward (Rådet for Teknologi og Innovation, 2008).

In an OECD report analysing the Oresund Region, factors such as removing bureaucratic and legislative obstacles as well as promoting transborder cooperation between firms and institutions are pointed out as constraints on innovation in the region (OECD, 2003). This is exactly why a Nordic initiative on cloud computing should be considered over a set of individual national initiatives.

- In other words, a common Nordic initiative on cloud computing seems to be a very viable approach towards driving public innovation 



\section{Conclusion}

Facing the challenge of having to deliver more with less, the Nordic countries turn to IT and digitalisation strategies as a means of reaching the goal of a more effective and innovative public sector.

Cloud computing is a complex of emerging technologies which have the promising potential to be part of the solution to steer the public sector in the right direction. The benefits of cloud computing are, among others, cost effectiveness, flexibility and scalability and green savings. Furthermore, cloud computing has the potential to support development towards a more innovative public sector. Innovation means collaborating on getting from knowledge to value - and getting there fast. As an emerging technology, cloud computing will encourage change and promote new products and service models in the public sector. In addition, cloud computing such as Software as a Service offers collaboration software which can be utilised as an additional driver for public innovation.

The Nordic countries have a solid foundation for taking up cloud computing due to the high level of e-readiness regarding both infrastructure and adaption of new technology. Furthermore, Nordic innovation capabilities are world leading, and the countries all consider IT as a means of overcoming some of the present day challenges. Finally, the Nordic climate is an enabler towards attracting data centres due to the "clean power" and inexpensive cooling.

However, there are still barriers to overcome before we can embrace cloud computing in the public sector, especially regarding legal issues on data protection, lack of interoperability (vendor lock-in) and difficulties regarding integration of cloud solutions with existing business applications.

This study has argued, that these barriers can be overcome faster with Nordic cooperation. The next part of the study proposes specific actions of such cooperation. 



\section{Proposed Actions}

The public sector is facing the challenge of delivering more with less without compromising quality. This study has argued that the benefits of cloud computing can help meet the challenge, and that this can be done faster when cooperating in the Nordic region. To enable this cooperation, it is suggested, that the Nordic Coucil of Ministers develop and publish a common Nordic strategy or policy for cloud computing. Furthermore, the study has identified a range of initiatives organised in five areas of cooperation. To ensure a mutual and integrated approach, it is suggested to organise the initiatives under a working group as illustrated in the figure below. The purpose of the working group and the suggested initiatives is to make cloud cooperation a high priority area in the Nordic region.

\begin{tabular}{|c|c|c|c|c|}
\hline \multicolumn{5}{|c|}{ Nordic Public Cloud Cooperation } \\
\hline $\begin{array}{l}\text { Knowledge } \\
\text { Sharing }\end{array}$ & Regulations & Standardisation & $\begin{array}{l}\text { Procurement } \\
\text { processes }\end{array}$ & $\begin{array}{l}\text { Attracting } \\
\text { Datacenters }\end{array}$ \\
\hline \multicolumn{5}{|l|}{$\begin{array}{l}\text { Products of } \\
\text { cooperation }\end{array}$} \\
\hline $\begin{array}{l}\text { - Reference cases } \\
\text { - Vendor solutions } \\
\text { overview } \\
\text { - Monitoring } \\
\text { overview } \\
\text { - Establishment of } \\
\text { Annual Public } \\
\text { Cloud Innovation } \\
\text { Award }\end{array}$ & $\begin{array}{l}\text { - Overview of } \\
\text { decision made by } \\
\text { law } \\
\text { - Cooperation with } \\
\text { Nordic data } \\
\text { protection } \\
\text { agencies }\end{array}$ & $\begin{array}{l}\text { - Guidelines and } \\
\text { standardisation } \\
\text { principles } \\
\text { - Study on } \\
\text { potential for } \\
\text { common } \\
\text { components and } \\
\text { Pilot project } \\
\text { - Nordic Public } \\
\text { Cloud Tool Box }\end{array}$ & $\begin{array}{l}\text { - Common service } \\
\text { descriptions } \\
\text { - Common } \\
\text { framework } \\
\text { agreements } \\
\text { - Analysis of } \\
\text { possible attraction } \\
\text { of data centers }\end{array}$ & $\begin{array}{l}\text { Common } \\
\text { marketing } \\
\text { presentation } \\
\text { s on the } \\
\text { Nordic } \\
\text { region as a } \\
\text { standardised } \\
\text { and well- } \\
\text { functioning } \\
\text { area for data } \\
\text { centers }\end{array}$ \\
\hline \multicolumn{5}{|l|}{$\begin{array}{l}\text { Annual } \\
\text { activities }\end{array}$} \\
\hline $\begin{array}{l}\text { - Monitoring } \\
\text { overview report }\end{array}$ & $\begin{array}{l}\text { Annual report on } \\
\text { public regulation } \\
\text { on Cloud } \\
\text { Computing }\end{array}$ & $\begin{array}{l}\text { - Annual update on } \\
\text { standardisation } \\
\text { initiatives and } \\
\text { guidelines }\end{array}$ & $\begin{array}{l}\text { - Overview of } \\
\text { framework } \\
\text { agreements }\end{array}$ & $\begin{array}{l}\text { - Annual status } \\
\text { report }\end{array}$ \\
\hline
\end{tabular}

The five "pillars" of the Nordic cooperation on cloud computing are described below.

\subsubsection{Knowledge sharing}

As argued above, knowledge sharing can be an enabler for public sector companies to overcome some of the issues that arise when pursuing the shift towards cloud computing. Knowledge sharing could be in the form of a shared information portal. Products of this collaboration should be: 
- Reference cases on existing cloud solutions

- A common database and knowledge centre on vendor solutions and opportunities

- Common monitoring of progress and situation in the Nordic countries

Furthermore, it is suggested, that an annual "Nordic Public Cloud Innovation Award" - awarded for the best public cloud solution in the Nordic region in favour of improving public innovation or welfare - be established.

\subsubsection{Regulations}

Since the issues related to data protection and the laws on protection of personal data have shown to be one of the biggest barriers towards embracing cloud computing, it is suggested, that this should be a target area for knowledge sharing and best practice, namely on regulation and decisions made by law on cloud solutions.

Furthermore, it is suggested that the Nordic Council acts as enabler in order to create greater cooperation and knowledge sharing about the legal demands troughout the Nordic countries. The purpose is to discuss the legal requirements and to create a unified approach towards cloud computing among the local data protection agencies. This work should lead to the publishing of guidelines (encryptions rules and best practice), a common stand on data security policy and other publications on how to handle regulations in a cloud context.

\subsubsection{Standardisation}

Cloud computing is an emerging technology and standards are not yet ready. To make future Nordic cooperation and implementation of cloud solutions possible and more efficient, it is suggested that common standards are developed. The standardisation initiatives on this area are to be seen as an addition to the other standardisation initiatives on national, European and international levels, and aim to reduce vendor lock in and improve common solutions in the long run. It is proposed to prioritise the standardisation initiatives in the following order:

- Infrastructure - servers, storage and network

- Platform - operating systems, databases, web

- Software - solutions

The Nordic cooperation initiative should conduct a study to identify the potential and the business case in common solutions. It is proposed to find a common Nordic project to act as proof of concept. The areas of 
interest could be: GIS, property and housing data, environmental information and data, agriculture data, health care information.

Finally, it is proposed to create a Nordic Public Cloud Tool Box, morespecificly tools and methods for making a decision framework on cloud solutions including templates and taxonomies. The tool box could include business cases, templates and security guidelines.

\subsubsection{Procurement processes and tools}

To assist public organizations in the procurement process, common service descriptions and minimum requirements should be discussed and published by the working group. Common framework agreements and common procurement processes and tools - such as vendor assessments or requirement specifications - can be developed.

SKI (Denmark), Hansel (Finland) and Statens inköpscentral (Sweden) could work together in harmonizing technical and legal requirements, which would lead to a more predictable market for the vendors and a safer procurement process for the public sector.

\subsubsection{Attracting Data Centres}

Based on common intensified communication activities and marketing, the Nordic region should be presented as a standardised and wellfunctioning area with a high maturity on cloud computing and an attractive position for data centres. This will help attracting data centres and potential solution vendors.

\subsubsection{The working group}

As mentioned above, it is suggested that these initiatives should be organised under a Nordic working group or public cooperation body. The working group can be established under The Nordic Counsil of Ministers or in another constellation. The working group should focus on the initiatives mentioned above.

The initiatives above all have a reporting and coordination task. It is important, that the different initiatives are coordinated and knowledge and learning is shared. 



\section{Bibliography}

Biddick, M. (2011, April 16). Cloud Computing's Tipping Point. Retrieved October 11, 2011, from Information Week Government: http://informationweek.com/news/ government/cloud-saas/229401705

Carr, N. (2008). The Big Switch.

Cearley, D., \& Phifer, G. (2010). Case Studies in Cloud Computing. Retrieved October 11, 2011, from Gartner.com: http://www.gartner.com/it/content/1286700/ 1286717/march_4_case_studies_in_cloud_computing_dcearley_gphifer.pdf

Danish Agency for Science, Technology, and Innovation. (2008). Strategy for increased innovation in the public sector (Danish). Danish Agency for Science, Technology, and Innovation.

Danmarks Statistik. (2010, January 24). Nyt fra Danmarks Statistik Nr. 32. Retrieved October 11, 2011, from Danmarks Statistik: http://www.dst.dk/pukora/epub/Nyt/2011/NR032.pdf

Datainspektionen. (2011, September 30). Risker med otydliga avtal för molntjänster. Retrieved October 11, 2011, from Datainspektionen: http://www.

datainspektionen.se/press/nyheter/risker-med-otydliga-avtal-for-molntjanster/

Datatilsynet. (2010, June 26). Udtalelse i forbindelse med anmeldelse af "Google Apps online kontorpakker med kalender og dokumenthåndtering". Retrieved June 29, 2011, from Datatilsynet: http://datatilsynet.dk

Digi.no. (2011, October 3). Dette vil ikke Datatilsynet "rushe". Retrieved October 11, 2011, from Digi.no IT-bransjens nettavis: http://www.digi.no/879410/dette-vilikke-datatilsynet-\%ABrushe\%BB

Digi.no. (2011, July 7). Narvik må svare for Google Apps. Retrieved October 11, 2011, from Digi.no IT-bransjens nettavis: http://www.digi.no/873387/narvik-maasvare-for-google-apps

Dutta, S., \& Mia, I. (2011). The Global Information Technology Report. (S. Dutta, \& I. Mia, Eds.) World Economic Forum and INSEAD.

Elbak, A., \& Andersen, P. (2009). Potential Server and Datacenter CO2 Savings in Denmark. IDC.

European Grid Infrastructure. (2011, May 23). Digital Agenda: How to exploit cloud computing in Europe? Retrieved October 11, 2011, from European Grid Infrastructure: http://www.egi.eu/about/news/news_0058_EC_cloud_computing_ consultation.html

Finnish Government. (2010). Tuottava ja uudistuva Suomi - Digitaalinen agenda vuosille 2011-2020. Retrieved October 11, 2011, from Lvm.fi: http://www.lvm.fi/c/document_library/get_file?folderId=913424\&name=DLFE11384.pdf\&title=Tuottava $\% 20 \mathrm{ja} \% 20$ uudistuva $\% 20$ Suomi $\% 20$-selonteko

Gartner. (10. August 2011). Gartner's 2011 Hype Cycle Special Report Evaluates the Maturity of 1,900 Technologies. Retrieved October 11, 2011 from Gartner: http://www.gartner.com/it/page.jsp?id=1763814

Gartner. (10. August 2011). Gartner's 2011 Hype Cycle Special Report Evaluates the Maturity of 1900 Technologies. Retrieved October 11, 2011 from Gartner: http://www.gartner.com/it/page.jsp?id=1763814

Greenpeace International. (2011). How Dirty is Your Data? A Look at the Energy Choices that Power Cloud Computing. Greenpeace International.

Guevara, J. K., Hall, L., \& Stegman, E. (2010). IT Key Metrics Data 2011: Key Infrastructure Measures: IT Help Desk Analysis. Gartner Group. 
Hoff, P. M. (2010). Sikkerhetsdagens årlige undersøkelse om informasjonssikkerhet i norske bedrifter. Presentation from the "Nasjonal Sikkerhetsdag"

IT \& Telestyrelsen. (2011). Cloud Computing og de juridiske rammer - En vejledning om lovgivningskrav og kontraktmæssige forhold i forbindelse med cloud computing. IT \& Telestyrelsen.

Jackson, K. L. (2009). Government Cloud Computing. Dataline LLC.

Jeffery, K., \& Neidecker-Lutz, B. (Eds.). (2010). The Future of Cloud Computing. European Commission- Information Society and Media.

Kammarkollegiet. (2010). Förstudie - Programvaror 2010 - Ärendenr 93-10-14. Kammarkollegiet.

Kundra, V. (2010, December 9). 25 Point Implementation Plan to Reform Federal Information Technology Management. Retrieved October 11, 2011, from Cio.gov: http://www.cio.gov/documents/25-Point-Implementation-Plan-to-ReformFederal\%20IT.pdf

Kundra, V. (2011, February 8). Federal Cloud Computing Strategy. Retrieved October 11, 2011, from Cio.gov: http://www.cio.gov/documents/Federal-CloudComputing-Strategy.pdf

Kundra, V. (2010, June 8). Public Sector Cloud Computing Case Study: Army Experience Center. Retrieved October 2011, from CIO.gov: http://www.cio.gov/pages.cfm/ page/Public-Sector-Cloud-Computing-Case-Study-Army-Experience-Center

McClure, D. (2010, Juli 1). Statement of Dr. David McClure, Associate Administrator. Office of Citizen Services and Innovative Technologies, General Service Administration. Retrieved October 2011, from GSA: http://www.gsa.gov/portal/content/ 159101

Melin, D. (2011, September 8). (S. Ørslund, Interviewer)

Moore, G. A. (1999). Crossing the Chasm.

Møberg, E., Danielsen, A. H., Damgaard, T. T., Christensen, S., Weeke, S., Bundgaard, N., et al. (Eds.). (2010). IT i Praksis (r) 2010 - Strategi, trends og erfaringer i danske virksomheder. Rambøll Management Consulting A/S.

NIST (Sept. 2011). The NIST Definition of Cloud Computing. National Institute of Standards and Technology, U.S. Department of Commerce. Retrieved November 1, 2011, from NIST: http://csrc.nist.gov/publications/nistpubs/800-145/SP800-145.pdf

Nordfors, L., Ericson, B., Lindell, H., \& Lapidus, J. (2009). eGovernment of Tomorrow Future Scenarios for 2020. Vinnova.

OECD. (2003). OECD Territorial Reviews: Oresund, Denmark/Sweden. OECD.

OECD. (2003). OECD Territorial Reviews: Oresund, Denmark/Sweden 2003. OECD.

OECD/Eurostat. (2005). Oslo Manual - Guidelines for Collecting and Interpreting Innovation Data. OECD/Eurostat.

Prime Minister's Office. (2008). Iceland the e-Nation. Icelandic Government Policy on the Information Society. Prime Minister's Office.

Regeringen / KL / Danske regioner. (2011). Den digitale vej til fremtidens velfærd. Den fællesoffentlige digitaliseringsstrategi 2011-2015. Økonomistyrelsen.

Rådet for Teknologi og Innovation. (2008). Strategi for styrket innovation i den offentlige sektor. Forsknings- og Innovationsstyrelsen.

Stensaker, B., Borgen, J. S., Musial, K., \& Schwach, V. (2001). Evaluation of Nordplus. Retrieved October 2011, from Norden.org: http://www.norden.org/en/ publications/publications/2011-521

Teknik- og Miljøforvaltningen. (2010). Praktiske erfaringer med cloud. Retrieved October 11, 2011, from Digitalisér.dk: http://digitaliser.dk/resource/446674/ artefact/SimonKaastrupOlsen_CCkonference_13012010.pdf

The Brookings Institution. (2010, April 7). The Economic Goals of Cloud Computing. Retrieved October 11, 2011, from Brookings.edu: http://www.brookings.edu/ / media/Files/events/2010/0407_cloud_computing/20100407_cloud_computing.pdf 
The Economist Intelligence Unit. (2010). Digital Economy Rankings 2010. Beyond ereadiness. The Economist Intelligence Unit Limited.

(2010). The Innovation for Development Report 2010-2011. In A. López-Claros (Ed.). Zirn, T. (2011, May 27). Kommunerna ska ut i molnet. Retrieved October 11, 2011, from IDG.se: http://www.idg.se/2.1085/1.388032/kommunerna-ska-ut-i-molnet Aasrud, R. (2011, June 17). Regjeringens digitale agenda. Retrieved October 11, 2011, from Fornyings-, Administrasjons- og Kirkedepartementet: http://www.regjeringen. no/en/dep/fad/aktuelt/taler_og_artikler/minister/taler-og-artikler-av-fornyings-og-kirke/2011/regjeringens-digitale-agenda.html?id=648394 



\section{Sammenfatning}

Denne rapport er udarbejdet for Nordisk Ministerråd og undersøger, på hvilke punkter det vil være en god ide, at indlede et nordisk samarbejde om cloud computing. Rapporten er et oplæg til diskussion og skal indlede en debat om, hvilke fordele cloud computing kan give de offentlige myndigheder i norden. Rapporten viser, at hvis fordelene skal indfries, er det nødvendigt at fjerne de barrierer der er for yderligere brug af cloud computing. Det foreslås i rapporten, at der indledes et samarbejde på tværs af de nordiske lande om netop dette.

Rapporten er bestilt af den uformelle rådgivningsgruppe for itdirektører under Nordisk Ministerråd og er første indlæg i en debat om, hvor det kan give værdi at samarbejde om cloud computing i de nordiske lande. Arbejdet skal også føre til, at der opnås en fælles viden om cloud computing i de nordiske lande.

Rapporten indledes med en definition af cloud computing. Dernæst ses der på, hvilke fordele der er ved brug af cloud computing og på hvilke barrierer der er for yderligere brug.

Rapporten undersøger, hvor it-parate de nordiske lande er, og det vises, at de nordiske lande i høj grad har et rigtig godt udgangspunkt for at komme i gang med cloud computing. Det skyldes den meget høje itparathed der er i de nordiske lande, hvor vi har en solid infrastruktur og generelt er gode til at anvende ny teknologi.

Dernæst undersøger rapporten, hvilke områder det vil give værdi at samarbejde om i de nordiske lande. Rapporten viser, at et samarbejde kan føre til en hurtigere gevinstrealisering når det kommer til brugen af cloud computing, og at dette kan føre til offentlig innovation.

Rapporten slutter med at anbefale en række handlinger for den offentlige sektor i norden. Hvis de nordiske lande indleder et samarbejde på disse områder, er det rapportens konklusion, at de nordiske lande vil kunne lave en hurtigere gevinstrealisering, når det kommer til cloud computing. 



\section{Appendix}

\subsection{A. Working group}

This report has been produced by the Nordic cloud computing working group established by the group of IT directors in the Nordic Council of Ministers. Implement and Trifork has excecuted the analysis and the following report.

\begin{tabular}{llll}
\hline Country & Name & Title & Company \\
\hline Denmark & $\begin{array}{l}\text { Morten Jørsum } \\
\text { Camilla Grynnerup Fisker } \\
\text { Per-Olav Gramstad }\end{array}$ & $\begin{array}{l}\text { Head of Section } \\
\text { Head of Section } \\
\text { Chief Advisor }\end{array}$ & $\begin{array}{l}\text { Agency for Digitisation } \\
\text { Agency for Digitisation } \\
\text { Agency for Digitisation }\end{array}$ \\
Sweden & Daniel Melin & Procurement officer & Kammarkollegiet \\
Norway & $\begin{array}{l}\text { Nina V. Aulie } \\
\text { Erik Hasle }\end{array}$ & ClO & Manager of ICT depatment \\
& & Directorate of Labour and Welfare / NAV \\
\end{tabular}

\subsection{B. List of interviews}

\begin{tabular}{llll}
\hline Country & Name & Title & Company \\
\hline Denmark & $\begin{array}{l}\text { Brian Winther } \\
\text { Søren Ulrich Vulff } \\
\text { Lene Sillasen }\end{array}$ & $\begin{array}{l}\text { Professor } \\
\text { Vice President } \\
\text { CEO }\end{array}$ & $\begin{array}{l}\text { Niels Bohr Institute } \\
\text { Agency for Governmental IT Services } \\
\text { Copenhagen Municipality, Sund- } \\
\text { heds-og omsorgsforvaltningen }\end{array}$ \\
Finland & $\begin{array}{l}\text { Aki Sipponen } \\
\text { Timo Valli }\end{array}$ & $\begin{array}{l}\text { ClO } \\
\text { Director }\end{array}$ & $\begin{array}{l}\text { Ministry of Defence } \\
\text { Iceland }\end{array}$ \\
& $\begin{array}{l}\text { Brandur Sigurjónsson } \\
\text { Gudmundur Hannesson }\end{array}$ & $\begin{array}{l}\text { Software engineer } \\
\text { Manager of consultancy division }\end{array}$ & $\begin{array}{l}\text { Finance Ministry } \\
\text { The National Land Survey of Iceland } \\
\text { The State Trading Center }\end{array}$ \\
& $\begin{array}{l}\text { Heidi Austlid } \\
\text { Per-Olav Stenseth }\end{array}$ & $\begin{array}{l}\text { Director } \\
\text { IT-strateg }\end{array}$ & $\begin{array}{l}\text { IKT-Norge } \\
\text { Norwegian Tax Administration }\end{array}$ \\
& $\begin{array}{l}\text { Tony Söderlund } \\
\text { Daniel Melin }\end{array}$ & $\begin{array}{l}\text { ClO } \\
\text { Procurement officer }\end{array}$ & $\begin{array}{l}\text { Salem Municipality } \\
\text { Kammarkollegiet }\end{array}$ \\
\hline
\end{tabular}

Cloud computing is widely recognised as a mean for bringing cost savings and better utilisation of resources to the IT departments and their limited budgets. Cloud computing, where IT is delivered as an ondemand pay-per-use service, is rapidly evolving from a hype to a serious alternative to traditional IT procurement. This development is vastly driven by big international players. If the Nordic region is to influence and gain from this development it is essential that the Nordic governments act now. 
This report sets the scene for a common understanding of the notion of cloud computing across the Nordic region. The report offers a list of recommendations for key action points where cooperation across the Nordic region will be beneficial in order to establish the Nordic region as a driving force for cloud computing in the public sector. 